\title{
Aromaterapie jako součást antropologického diskurzu
}

\author{
Barbora Půtová \\ Ústav etnologie, Filozofická fakulta, Univerzita Karlova, nám. Jana Palacha 2, 11638 Praha 1, Česká republika
}

Do redakce doručeno 23. záŕí 2019; k publikaci přijato 5. listopadu 2019

\begin{abstract}
AROMATHERAPY AS A PART OF ANTHROPOLOGICAL DISCOURSE
ABSTRACT This article deals with aromatherapy as a new subject of research for medical anthropology and ethnomedicine. It draws attention to the fact that while Western biomedicine has the monopoly on certain medical practices and provision of medical services, it allows for coexistence of traditional and/or alternative treatments and methods. The first part of the article focuses on defining aromatherapy as one of the natural holistic methods using essential oils as healing substances affecting the physical as well as mental aspects of the human body. Special attention is paid to analysing aromatherapy from the perspective of the patient's personal participation in the treatment, its control and creation of space for asserting values and standards influencing the quality of health and life. The following part describes in detail essential oils, their effects and technological procedures of their manufacture. Consequently, the article discusses the methods of application of essential oils. The last section of the article presents the history and describes various aspects of how essential oils are perceived today, their objective pharmacologic characteristics, how they influence personal experience, their cultural contexts and the formation marketing myths surrounding them. Speaking of marketing, the text elaborates on the issue of commodification of aromatherapy and essential oils, making the consumption of essential oils of primary importance. Essential oil characteristics are now increasingly dominated more and more by the semiotic layer linked with the meaning and symbols of their use.
\end{abstract}

KEY WORDS aromatherapy; essential oils; medical anthropology; ethnomedicine

\begin{abstract}
ABSTRAKT Studie je věnovaná aromaterapii jako nové oblasti výzkumů medicínské antropologie a etnomedicíny. Upozorňuje na skutečnost, že západní biomedicína sice disponuje monopolem na určité lékařské praktiky a poskytování zdravotních služeb, ale zároveň umožňuje koexistenci tradičních nebo alternativních léčebných praktik a metod. V první části studie je pozornost kladena na vymezení aromaterapie, která představuje jednu z př́rodních holistických metod, používající esenciální oleje jako léčebné látky působící jak na fyzickou, tak psychosociální dimenzi lidského těla. Zvláštní pozornost je věnována analýze aromaterapie z hlediska osobní účasti pacienta na léčbě, její kontrole a vytváření prostoru k uplatnění hodnot a norem ovlivňujících kvalitu zdraví a života. V další části jsou přiblíženy esenciální oleje, jejich účinky a technologické postupy jejich získávání. Studie neopomíjí ani způsoby aplikace esenciálních olejü. V poslední části studie je představena historie a současnost vnímání esenciálních olejů, jejich objektivní farmakologické vlastnosti, vliv na osobní zkušenosti, kulturní kontexty nebo utváření marketingových mýtů. V této souvislosti je rozvedena problematika komodifikace aromaterapie a esenciálních olejů, které se proměňují v tržní produkty. Primární se proto stávají způsoby spotřeby esenciálních olejů. Nad vlastnostmi esenciálních olejů tak začíná dominovat sémiotická vrstva související s významy a symboly jejich užívání.
\end{abstract}

KLÍČOVÁ SLOVA aromaterapie; esenciální oleje; medicínská antropologie; etnomedicína

\section{AROMATERAPIE V KONTEXTU ANTROPOLOGIE MEDICÍNY}

Antropologie medicíny představuje subdisciplínu sociokulturní antropologie, jejíž intenzivní rozvoj je zaznamenán od 50. let 20. století (Lieban 1977, Baer - Singer 1997). Její zájem byl nejdřive zaměřen na etnomedicínské přístupy ke zdraví a nemoci v domorodých kulturách, které se odlišují od biomedicínského modelu zdraví (van der Geest et al. 1996). Antropologie medicíny ale postupně obrátila pozornost k bio- 


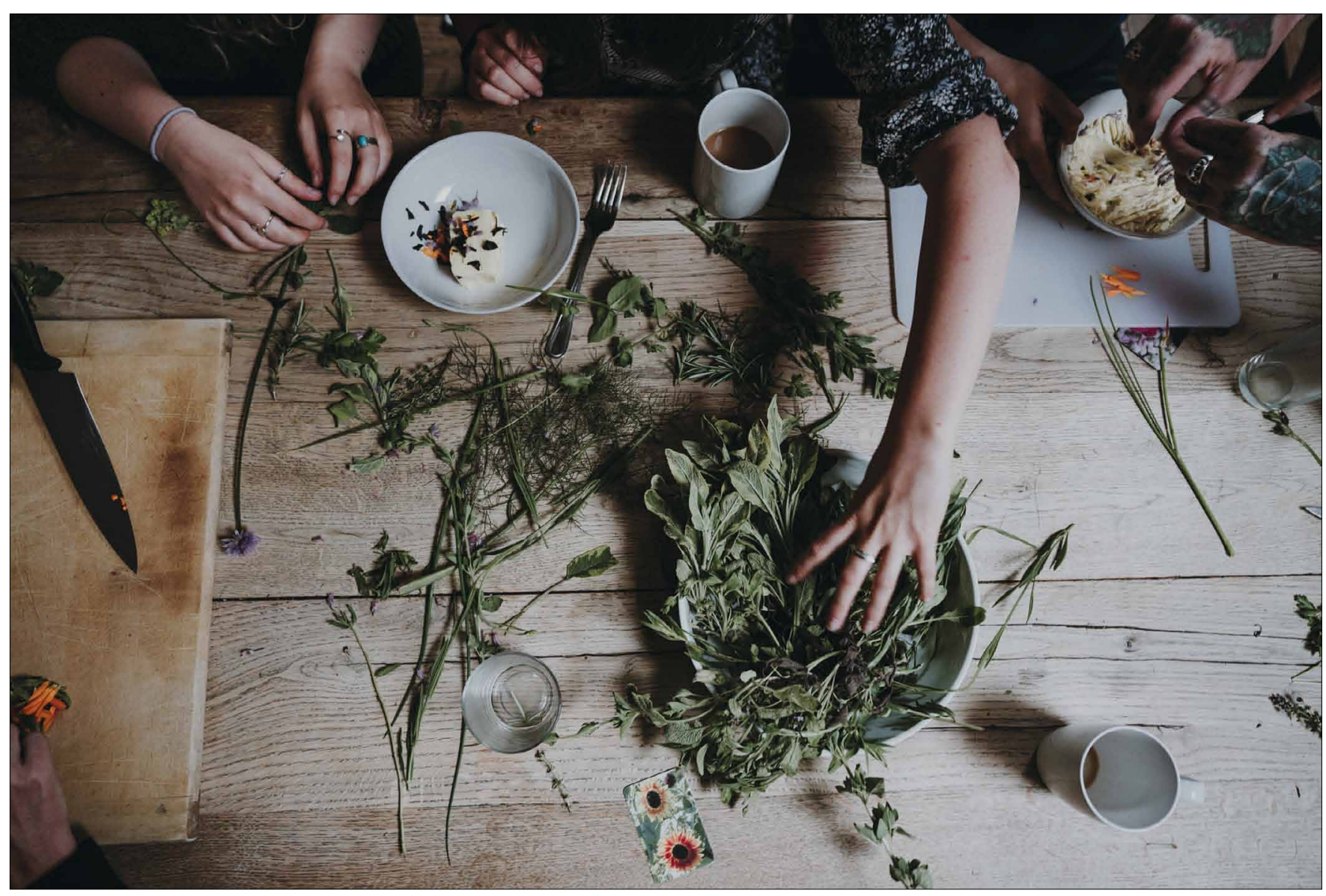

Aromaterapie je jednou z forem fytoterapie (bylinkářství), která však vedle esenciálních olejů zapojuje i další rostlinné výtažky a materiály. @ Sheri Vettel.

medicíně (západní, alopatická nebo konvenční medicína) jako kulturnímu fenoménu a předmětu výzkumu v západním světě (Hahn - Kleinman 1983; Slepičková - Šlesingerová - Šmídová 2012). Biomedicína totiž poskytuje „jedinečnou príležitost pochopit důsledky a omezení technologického rozvoje, vysoké specializace, institucionalizovaného rozdèlení mysli / tèla / společnosti, komplikovaného tělesného a redukcionistického zaměrení a silných sociálních nástrojů pro enkulturaci a ovládání účastníků. “(Hahn - Kleinman 1983, 323) Do popředí vstoupila také komparativní perspektiva biomedicíny a etnomedicíny, jejíž poznatky a zkušenosti se začaly uplatňovat v západní kultuře. Antropologický zájem se proto rozšíril o problematiku prevence a léčby nemocí, kulturní hegemonii biomedicíny, volbu terapie a alternativní léčby nebo fungování medicínského pluralismu (Gordon 1988, Lock - Nguyen 2010).

Užití aromaterapie v západním světě ilustruje trend dominantního postavení biomedicíny, která sice disponuje monopolem na určité lékařské praktiky a poskytování zdravotních služeb, ale zároveň umožňuje koexistenci tradičních léčebných praktik a metod. Medicínský pluralismus nabízí řadu léčebných technik a zároveň odráží hierarchii a sociální vztahy v moderních společnostech - „ve společnostech, kde se daří medicínskému pluralismu, vždy panuje trídní rozdělení. "(Frankenberg 1980, 198) Lékaři západní medicíny stále více začleňují různé metody tradiční terapie a etnomedicíny - od homeo- patie, akupunkturu přes fytoterapii až po aromaterapii do svého léčebného systému ve snaze vytvořit integrální, mezioborovou a komplementární medicínu. Mnozí pacienti navíc revalorizují nebo přinejmenším respektují tradiční léčbu a pouze utilitárně akceptují výhody vyplývající z biomedicíny (Stoner 1986; Synovitz - Larson 2013; Kř́ižová 2015). Zejména pacienti $\mathrm{z}$ vyšší střrední a střední třídy se uchylují k etnomedicíně, pokud biomedicína a její prostředky selhaly nebo jsou nevyhovující, a v neposlední řadě ji využívají jako komplementární doplněk biomedicíny. Používání rostlin a esenciálních olejů se osvědčuje jako bezpečná, zdravá a přirozená léčebná alternativa. Prostředí medicínského pluralismu je proto otevřeno svobodné volbě, v níž vystupuje osobní účast pacienta na léčbě a její kontrole a prostor $\mathrm{k}$ uplatnění jeho vlastních hodnot a přesvědčení týkajících se zdraví a života, které se stávají předmětem zájmu antropologie medicíny (Poole - Gessler 2005).

Jedním ze základních atributů a výzkumných aspirací obecné antropologie je studium člověka $\mathrm{z}$ biologické (biologická antropologie) a kulturní (kulturní antropologie) perspektivy. Antropologicky koncipovaný holistický, komparativní a interdisciplinární prístup lze uplatnit i na výzkum dvou různých dimenzí lidského těla a zpơsobů jeho léčení. Jedním ze zásadních zjištění současné biomedicíny je skutečnost, že mnoho nemocí má psychosomatický základ. Klasická západ- 


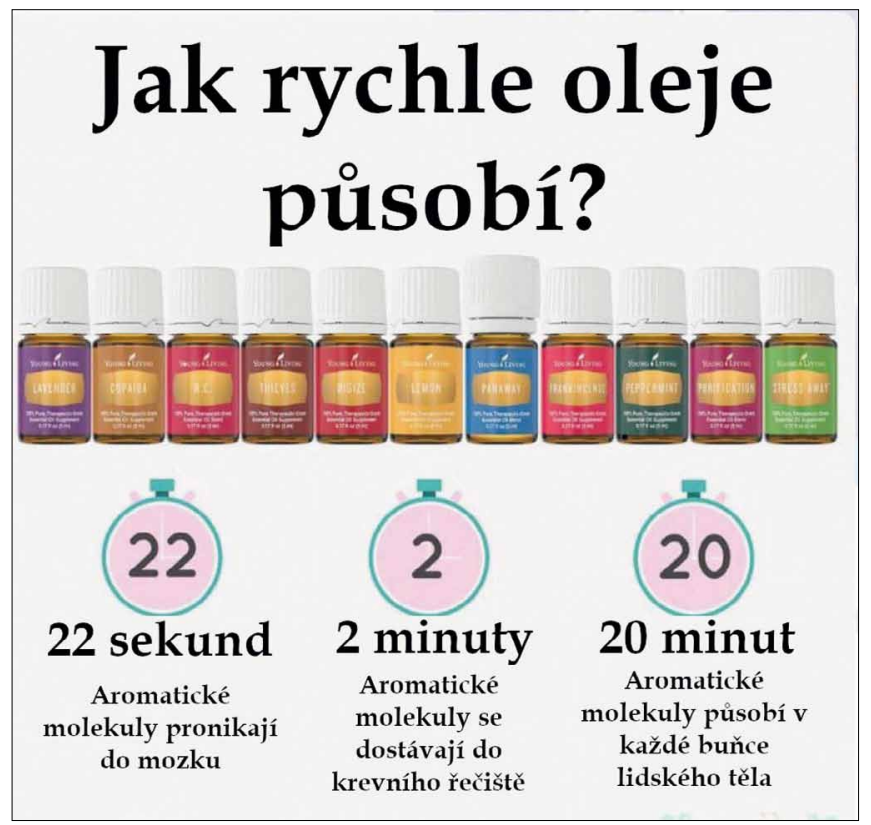

Jak rychle esenciální oleje působí @ Katrina Chambers.

ní biomedicína si na základě antropologických výzkumů alternativních př́stupů $\mathrm{k}$ nemoci a léčbě lidského těla (etnomedicína), které jsou praktikované v nezápadních domorodých společnostech, přiznala, že nemoc je nejen biologickým, ale i sociokulturním jevem. V ohnisku lékařského a antropologického výzkumu se tak ocitl esenciální olej, jeho vůně a léčebné fyziologické a sociokulturní účinky.

\section{VYMEZENÍ AROMATERAPIE}

Obohacení o poznatky a zkušenosti etnomedicíny se projevuje $\mathrm{v}$ prosazení aromaterapie, která představuje jednu $\mathrm{z}$ prrírodních holistických metod, používající esenciální oleje jako léčebné látky působící na fyzickou i psychosociální dimenzi lidského těla (Grosjean 2003). Aromaterapie je jednou $\mathrm{z}$ forem fytoterapie (bylinkářství), která však vedle esenciálních olejů zapojuje i další rostlinné výtažky a materiály. $\mathrm{V}$ domorodých kulturách se v závislosti na oblastech užívaly různé druhy esenciálních olejů za různými účely (Damianovi 1997; Snyder - Lindquist 2006). Také v současnosti jsou v aromaterapii esenciální oleje aplikovány nejenom k léčbě akutních a chronických stadií onemocnění, ale také pro prevenci, podporu nebo zlepšení fyzické, psychické a osobní pohody (well-being). Aromaterapie má mnoho uplatnění v léčbě širokého spektra onemocnění, která mohou být více či méně závažná. Aromaterapie je léčba vưní, ke které používáme čichové buňky a receptory v mozku (Tisserand 1992). Vonné látky stimulují čich a chut', regulují teplotu, tlak, dýchání, podporují činnost lymfatického i trávicího systému nebo nervové soustavy. Intenzivní vůně má vliv na procesy, které se odehrávají v mozku. Vủně se dostanou přímo do mezimozku, kde působí na limbický systém (emoční centrum) (Başer - Buchbauer 2010).

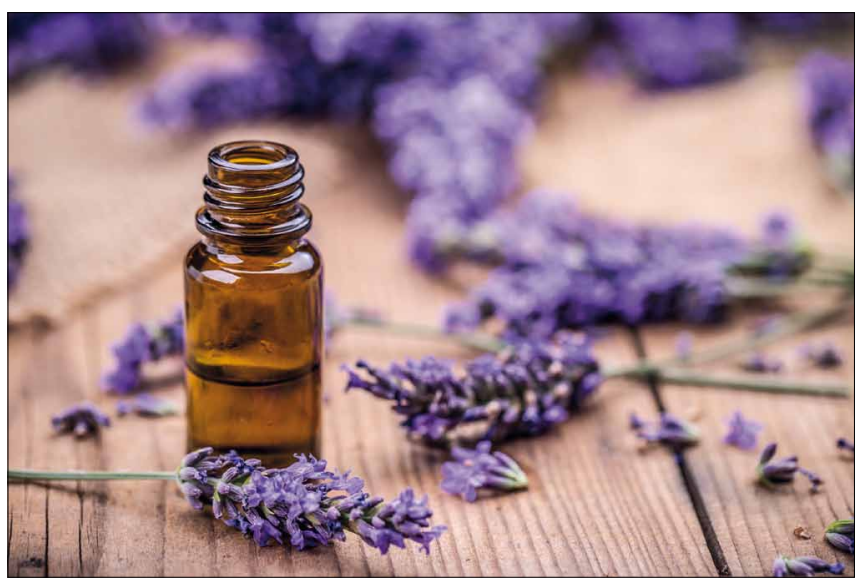

Aromaterapie je léčba vůní, ke které používáme čichové buňky a receptory v mozku. (C) Jo Burns.

V aromaterapii jsou esenciální oleje používány např́iklad ve spojení s masáží, inhalací, obklady nebo koupelemi. Pokud se oleje aplikují na kůži, proniknou účinné látky do krevního řčciště, a tím se dostanou do organismu. V aromaterapii je důležité zapojení klienta, který se $\mathrm{v}$ kooperaci s aromaterapeutem, lékařem nebo léčitelem podílí na výběru oleje nebo směsi esenciálních olejů (Harding 2003). U vzniku směsi esenciálních olejů je zároveň důležité zohlednit správné a požadované účinky, vzájemnou reakci esenciálních olejů, zdravotní stav klienta, jeho pocity a definování jemu př́ijemných vůní. Esenciální oleje mají široké využití, stejný esenciální olej je např́iklad možné aplikovat pro relaxaci i při léčbě infekčních onemocnění. Užívání esenciálních olejů zpravidla doprovází změna životního stylu, která se projevuje v odlišném přístupu $\mathrm{k}$ tělu a narůstající potřebě „schopnosti péče o sebe sama a naděje na vyšši kvalitu života" (Sommer 1996, 1241). $\mathrm{V}$ užívání esenciálních olejů nelze $\mathrm{v}$ mnoha př́padech očekávat okamžitý účinek, obvykle se projeví po mnoha hodinách nebo až po měsících. Účinnost čistých olejů nebo směsi se může stupňovat, pokud jsou ve správném poměru střídmá a vyvážená strava, pohyb a duševní hygiena (Tisserand 1992; Price 1993; Worwood 2001; Hertzka - Strehlow 2012).

„Mnozí aromaterapeuti a predstavitelé $z$ rad veřejnosti považují prírodní esenciální oleje za zcela bezpečné. To je založeno na mylné představě, že všechny byliny jsou bezpečné, protože jsou 'prírodní." (Lis-Balchin 2006, 75) Esenciální oleje jsou však zároveň vysoce koncentrované a lipofilní látky, a proto je při jejich užití potřeba zohledňovat možné a nepředvídatelné negativní účinky a reakce. Zdali je konkrétní esenciální olej bezpečný, záleží na mnoha faktorech, $\mathrm{k}$ nimž patří nejenom věk, pohlaví, zdravotní stav a historie klienta, ale také způsob a délka aplikace a medikace. Dávka je nejdůležitějším faktorem v bezpečném užití esenciálního oleje (Wheeler Robins 1999; Lis-Balchin 2006; Rhind 2012). Některé esenciální oleje aplikované $\mathrm{v}$ nevhodných dávkách nebo príliš vysoké koncentraci vyvolávají vedlejší účinky (nevolnost, bolesti hlavy anebo alergické reakce). Druh, způsob aplikace i dávkování esenciálních olejů je vždy žádoucí konzultovat s aromatera- 


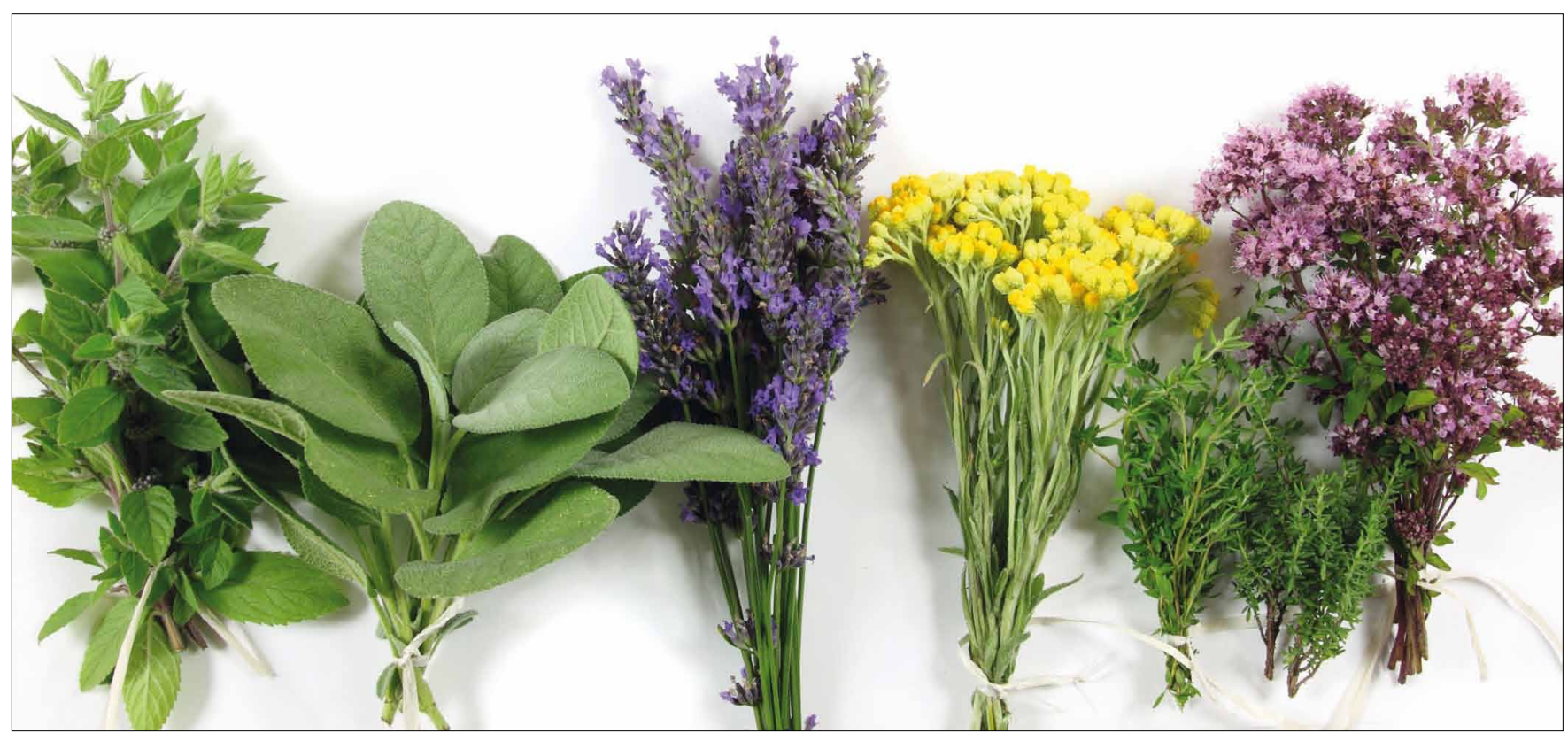

Esenciální oleje se získávají z různých částí rostlin, keřů a stromů. (c) Kathy Heshelow.

peutem, léčitelem nebo lékařem. Esenciální oleje mohou vyvolat různé kontraindikace s léčivými přípravky biomedicíny, nebot jejich chemické sloučeniny se mohou podílet na snížení účinnosti konvenčních léčiv nebo dokonce zhoršení zdravotního stavu jedince. ${ }^{1}$ Navíc esenciální oleje mohou produkovat toxiny, které způsobují poškození jater, plic a nervového systému (Hongratanaworakit 2004; Vigan 2010; Atkinson 2015). Další esenciální oleje charakterizuje fototoxicita. Zejména citrusové oleje obsahují furanokumariny, jež při vystavení kůže UV slunečnímu záření zvyšují riziko popálenin (Worwood 2016). Nedoporučuje se také vyhledávat mnohé esenciální oleje v období těhotenství a kojení. Během prvního trimestru těhotenství esenciální oleje představují riziko pro vyvíjející se plod. Vnitřní užití některých esenciálních olejů může vést až k potratu (Damianovi 1997). Zvýšené opatrnosti a znalosti účinků esenciálních olejů je potřeba i v př́padě aplikace esenciálních olejů dětem nebo zvířatům (Wheeler Robins 1999; Lis-Balchin 2006; Morag 2011).

\section{ESENCIÁLNÍ OLEJE}

Esenciální oleje, označované také jako éterické a aromatické oleje, esence nebo silice, představují tekuté koncentrované směsi těkavých aromatických sloučenin izolovaných $\mathrm{z}$ rostlin.

1 Např́klad pacient trpící hypertenzí by se měl vyhýbat stimulantům, jako je rozmarýn. Některé rostliny, k nimž se řadí fenykl, anýz a šalvěj, podporují tvorbu estrogenů v těle, jsou tak nevhodné pro pacientky s rakovinou prsu nebo vaječníků. Dále by v používání aromaterapie měli být opatrní jedinci s epilepsií, alergiemi, sennou rýmou, astmatem a kožními stavy jako ekzém nebo psoriáza (Tiran 2016).
Esenciální oleje se získávají z různých částí rostlin, keřů a stromů, jako jsou např́klad květy (růže), semena (koriandr), plody (citron), lodyhy (lilie), listy (eukalyptus), větve (jalovec), bobule (černý pepř), pryskyřice (kadidlo), šišky (cypřiš), kůra (kafrovník), dřevo (santalové dřevo), oddenky (zázvor) nebo kořeny (kosatec). Rostliny $\mathrm{v}$ přírodě při procesu opylování produkují vonné látky - rostlinné silice, kterými lákají opylovače. Produkce těchto vonných látek je přirozenou součástí života rostliny. $\mathrm{V}$ závislosti na tom, $\mathrm{z}$ jaké části rostliny silice pochází, se mění její složení. Množství silice v rostlině se odlišuje také podle podnebí, nadmořské výšky, zeměpisné oblasti, vlhkosti vzduchu, složení půdy, používání hnojiv a pesticidů, období sklizně a metody použité $\mathrm{k}$ extrakci oleje. Silice dodávají rostlině životní sílu a obsahují uhlovodíky a kyslíkaté látky, které fungují jako hlavní nositelé jejich vonných a chutových vlastností. Silice působí jako látky na odpuzení různého druhu hmyzu a býložravců. Uvolňují se, když je rostlina napadena plísní nebo hmyzem, nebo naopak přitahují hmyz k opylování rostliny (Hardingová 2003; Davisová 2005; Berger 2007; Farrer-Halls 2007; Tomášková 2014).

Vonné látky označujeme jako silice, nebot' stále neprošly chemickou změnou. Odborné pojmenování se liší tím, jaká metoda je použita. Po destilaci se ze silic stává esenciální olej, po extrakci tlakem získáváme esenci a po procesu enfleuráže nebo extrakci v rozpouštědlu získáváme absolue (Davisová 2005). Označení esenciální olej se ale používá „pro všechny oleje využívané v aromaterapii, přestože oleje získané jinými metodami vlastně nejsou čisté esenciální oleje." (Damianovi 1997, 14) Podle typu rostlinného orgánu se musí přizpůsobit i technika, jakou je rostlinná silice $\mathrm{z}$ rostliny získána. Esenciální oleje jsou intenzivně aromatické, velmi koncentrované a silné, proto se před užitím $\mathrm{v}$ aromaterapii ředí. Ve vodě jsou $\mathrm{v}$ podstatě nerozpustné, dobře se ale rozpouštějí v nosných 


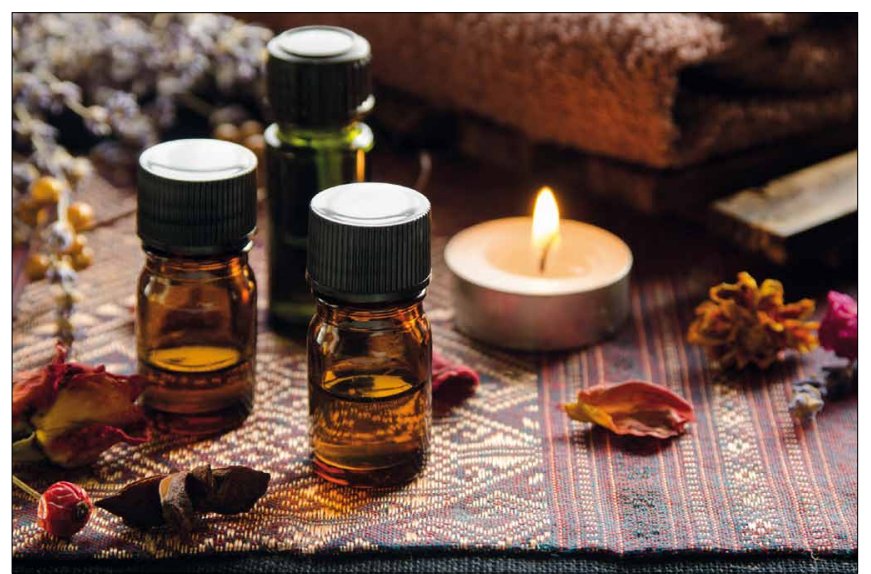

Esenciální oleje by se měly uchovávat nejlépe ve vzduchotěsných lahvičkách $\mathrm{z}$ tmavého skla, protože jsou velmi prchavé a na vzduchu se rychle vypařují. (c) Tania Morgan.

olejích, masti, gelu, medu a dalších organických rozpouštědlech. Esenciální oleje by se měly uchovávat nejlépe ve vzduchotěsných lahvičkách $\mathrm{z}$ tmavého skla (hnědé, zelené nebo fialové), protože jsou velmi prchavé a na vzduchu se rychle vypařují. Tři hlavní faktory zodpovědné za degradaci esenciálních olejů jsou vzduch, teplo a světlo. Při uchovávání ve tmě a chladu je zajištěna optimální ochrana bioinformací a k degradaci dochází v průběhu několika měsíců nebo let. Pokud se uchovává esenciální olej za neprríznivých podmínek, znehodnocení a snížení účinku obsahu nastane během několika dnů až týdnů (Nováková - Šedivý 1996; Wildwood 1996; Tisserand - Young 2014).

\section{ÚČINKY ESENCIÁLNÍCH OLEJU゚}

Každý esenciální olej charakterizuje specifická vůně a tvoří velké množství chemických složek. Tím je i všestranný a bezpečný, protože složky obsažené v oleji se často doplňují, podporují, vyvažují a společně působí léčivě na mysl i tělo (Bach 2010). Každý esenciální olej doprovází dominantní biologický účinek, charakter a vlastnosti, které slouží k jeho klasifikaci. Esenciální oleje, které stimulují pravou hemisféru mozku, vyvolávají emocionální reakce. Naopak esenciální oleje, jež stimulují levou hemisféru mozku, ovlivňují intelektuální procesy. Esenciální oleje mohou působit jako regulátory, stimulanty nebo sedativa. Jejich užití je široké a vysoce individuální, jejich účinky jsou mnohostranné a mnohaúrovňové. Každý člověk je jiný, má jiné potřeby a problémy, proto esenciální oleje působí na každého člověka odlišným způsobem. Esenciální oleje doprovází magnetický efekt, protože je přitahován k oslabenému místu, orgánu nebo funkci těla. Esenciální oleje mohou být antibakteriální, antivirové, antiparazitní, antioxidační, antikarcinogenní, analgetické a sedativní, relaxační, stimulační nebo insekticidní. Z hlediska působení na lidskou psychiku, mysl a emoce jsou účinky esenciálních olejů relaxační, stimulační nebo adaptační (Svoboda - Deans 1995; Laveryová 1998; Grosjean 2003).

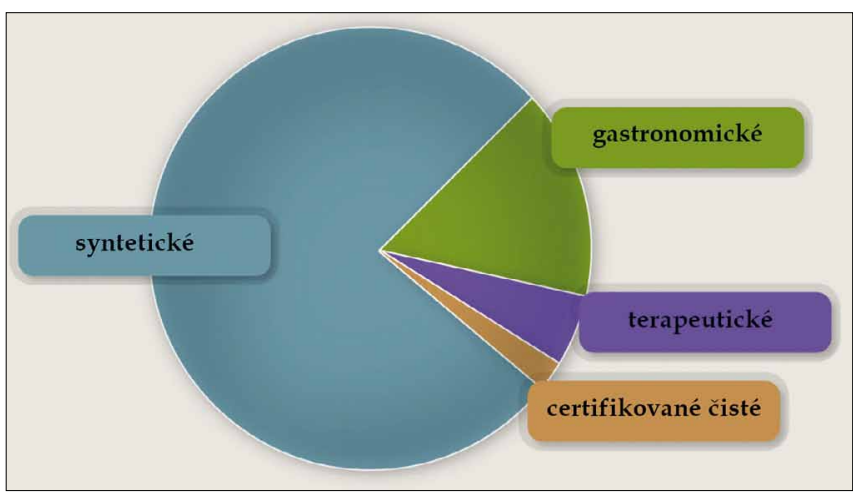

Typy esenciálních olejů. (C) OLiO Essentials.

Esenciální oleje jsou velmi často využívány kvưli antibakteriálním účinkům. O široké škále esenciálních olejů je známo, že mají antibakteriální vlastnosti. Antimikrobiální látky inhibují růst mikroorganismů (mikrobistatický účinek) nebo prŕmo vedou k jejich zániku (mikrobicidní účinek). Antimikrobiální aktivita esenciálních olejů závisí na jejich chemickém složení a obsahu jednotlivých komponent. Složení oleje je ovlivněno řadou faktorů, jako je druh rostliny, způsob a podmínky pěstování, zpracování a uchovávání rostlinného materiálu. Antimikrobiální aktivitu esenciální oleje vykazují vlivem fenolových sloučenin a uhlovodíků. Mezi esenciální oleje, které mají silné antimikrobiální vlastnosti proti vybraným kmenům bakterií, patří například skořice, hřebíček, rozmarýn, pelargonie, citron, limetka, šalvěj nebo pomeranč (Swamy Akhtar - Sinniah 2016).

Esenciální oleje jsou zdrojem antivirotických látek, které jsou schopné potlačit reprodukci virů různými způsoby. Mohou bránit jejich replikaci nebo šírení z buňky do buňky. Např́íklad čajovníkový esenciální olej projevuje vysokou úroveň antivirové aktivity proti Herpes simplex viru typu 1, který je původcem oparu nejčastěji na rtech. Dalšími vhodnými posilovači imunity jsou esenciální oleje z borovice, oregana, bergamotu, skořice, tymiánu nebo citrónové verbeny (Cooksley 2002).

Některé esenciální oleje jsou účinné v léčbě parazitárních nemocí, zejména proti endo- a ektoparazitům, jejichž hostitelem může být člověk i zvíře. Jejich důležitou vlastností je hydrofobnost, která umožňuje esenciálnímu oleji proniknout buněčnou membránou parazita a usmrtit ho ovlivněním cytoplazmatické metabolické dráhy nebo organel. Antiparazitními účinky se vyznačuje například levandulový nebo tymiánový esenciální olej (Chouhan - Sharma - Guleria 2017).

Mezi esenciálními oleji vykazují vybrané druhy antioxidační účinky, které omezují aktivitu volných radikálů a snižují pravděpodobnost jejich vzniku. Tyto esenciální oleje obsahují fenolytické sloučeniny, jako jsou karnosol nebo rosmadifenol, jež vykazují silnou antioxidační aktivitu. K esenciálním olejům s těmito sloučeninami patří černucha setá, rozmarýn, tymián, šalvěj nebo rakytník (Aazza - Lyoussi - Megías et al. 2014). Esenciální oleje nabízejí i antikarcinogenní účinky. Aktivita silic se projevuje v redukci lokálního nádoru nebo zabraňování 


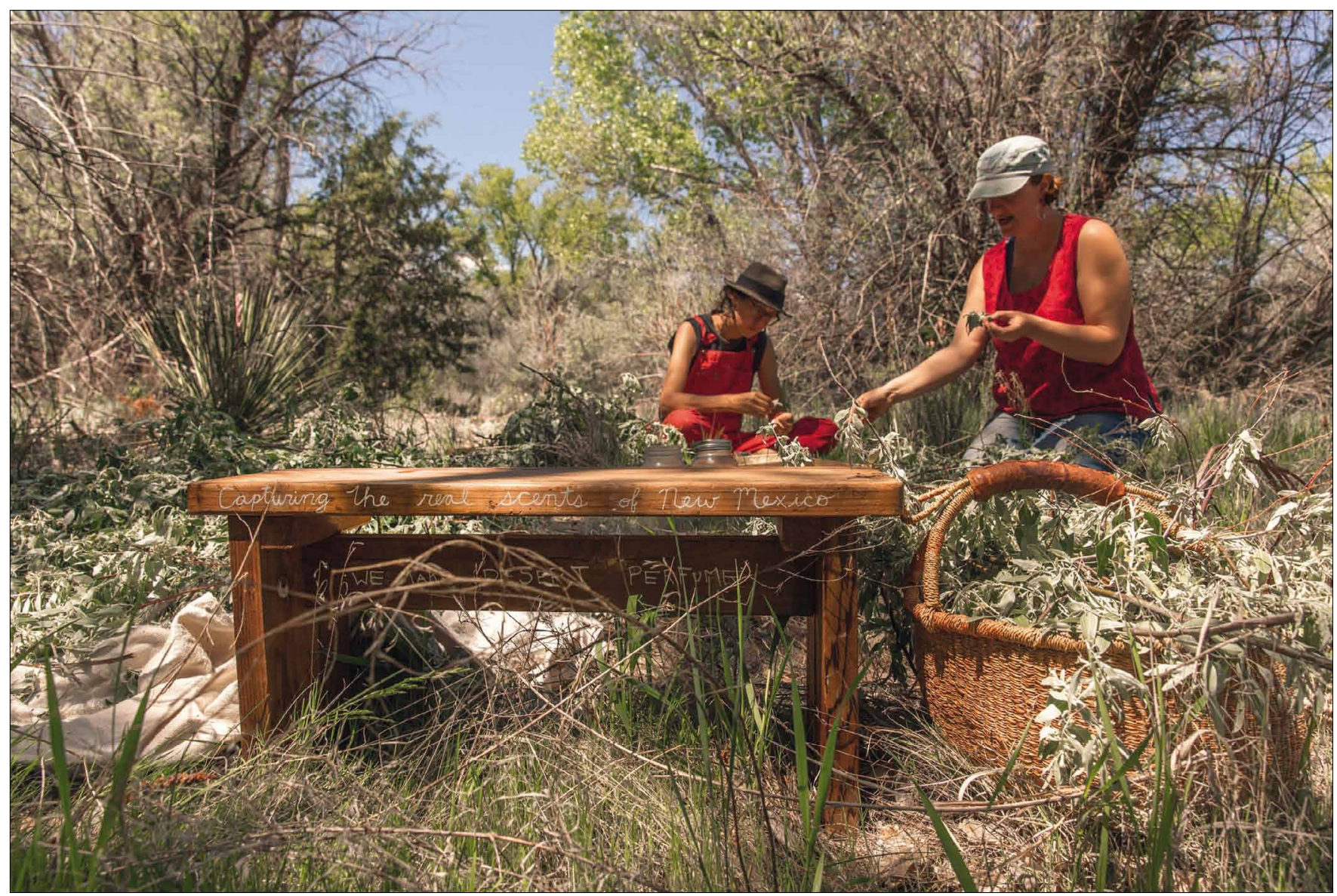

Př́prava esenciálního oleje vyžaduje důkladnou znalost rostlin, jejich prostředí a období sběru. ๑ Calla in Motion.

proliferace nádorových buněk. Antikarcinogenní účinky projevují esenciální oleje z kapary trnité, argánie trnité, voňatky citrónové, čajovníku nebo vanilky (Calcabrini - Stringaro - Toccacieli et al. 2004).

Esenciální oleje jsou vyhledávané pro své analgetické a sedativní účinky $\mathrm{k}$ úlevě od bolesti a k dosažení analgezie. Syntetická analgetika působí sice rychleji než léčiva prrírodní, ale doprovází je nepř́ijemné vedlejší účinky. Nejznámějším lokálním anestetikem je esenciální olej z hřebíčku. Analgetické a sedativní účinky mají esenciální oleje z koriandru, šafránu, máty nebo levandule lékařské (Skaria 2007).

Pro esenciální oleje a jejich složky jsou charakteristické i insekticidní účinky proti mnoha škůdcům, jako např́íklad proti hmyzu (komáŕi, mouchy nebo mšice) nebo broukům (nosatec). Esenciální olej získaný z bazalky a levandule působí proti mouchám domácím a mšicím. Dalšími oleji, které lze využít proti škůdcům na rostlinách, jsou esenciální oleje z bergamotu, anýzu, šalvěje, pelargonie, máty peprné nebo čajovníku (Pavela 2006).

Esenciální oleje vykazují také relaxační účinek, v jehož průběhu dochází $\mathrm{k}$ uvolnění organismu, ke snížení svalového, nervového a mentálního stresu. Relaxační účinky také napomáhají rozvoji osobnosti, zvyšují sebedůvěru, trpělivost a vyrovnanost. Relaxace podporuje potěšení smyslů, schopnost koncentrace pozornosti a imaginace a uvolňuje představivost.
Relaxačně působí různé esenciální oleje, $\mathrm{k}$ nimž patří např́íklad oleje z levandule, meduňky, růže, ylang-ylangu, mandarinky, neroli nebo rozmarýnu (Lis-Balchin 2006).

Některé esenciální oleje působí stimulačně a regulují tělesnou i duševní aktivitu organismu. Stimulační účinek se projevuje ve zvýšené duševní a fyzické výkonnosti, povzbuzuje a navozuje pocit síly a energie, potlačuje stres, únavu nebo úzkost a zlepšuje koncentraci. Stimulačními účinky se vyznačují esenciální oleje z itsey cubeby, citronové trávy, skořice, grapefruitu nebo pačule obecné (Başer - Buchbauer 2010).

Mnohé esenciální oleje charakterizuje adaptogenní účinek. Podporují organismus v adaptaci na životní změny, zvyšují jeho odolnost proti vnitřním a vnějším stresovým podnětům a obranyschopnost. Esenciální oleje s adaptogenními účinky umožňují přizpo̊sobovat se rychleji nebo lépe změněným podmínkám a lépe odolávat stresům, jež vznikají v důsledku zvýšených nároků na psychický a fyzický výkon, vystavení nepříznivému působení prostředí nebo vlivem meteopatických projevů. Aktivují nespecifickou obranyschopnost působením na různé orgány, odolnost proti infekci a nádorům a jsou užitečné $\mathrm{v}$ př́ípadech astenie a $\mathrm{v}$ období rekonvalescence. $\mathrm{K}$ adaptogenním esenciálním olejům se řadí palma rosa, borovice, bergamot, rozmarýn, levandule nebo citronová tráva (Worwood 2001; Snyder 2019). 


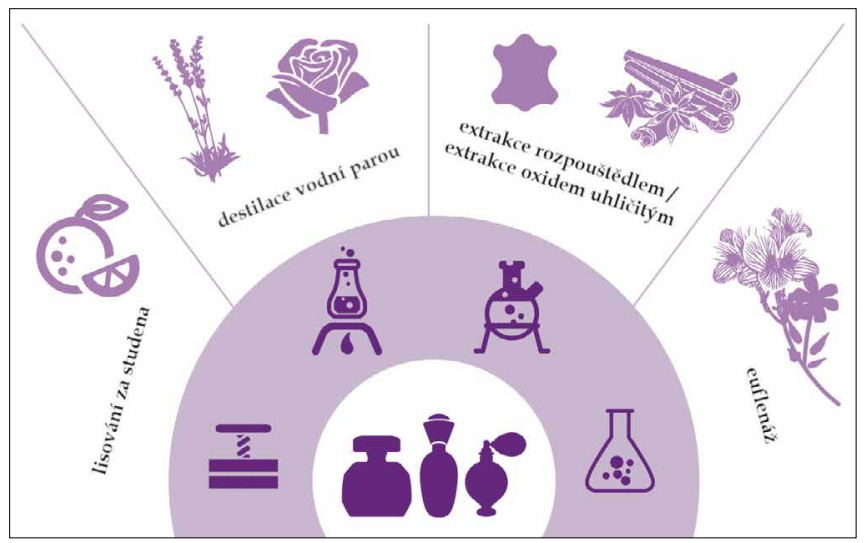

Technologické postupy výroby a získávání esenciálních olejů. (c) Venera Cosmetics.

\section{TECHNOLOGICKÉ POSTUPY VÝROBY A ZÍSKÁVÁNÍ ESENCIÁLNÍCH OLEJŮ}

Existuje několik technologických postupů, jejichž prostř̌ednictvím získáváme esenciální oleje ze sušeného i čerstvého rostlinného materiálu. Každá rostlina se odlišuje stavbou těla, vlastnostmi i vůní, proto se při prŕpravě vzorku a extrakci oleje používají různé postupy výroby. „Zvolené postupy závisí na části rostlin, $z$ nichž má být olej extrahován, na odolnosti oleje vůči teplu a na náchylnosti složek oleje $k$ chemickým reakcím." (Hamid - Aiyelaagbe - Usman 2011, 87) Esenciální oleje získané $\mathrm{z}$ rủzných částí stejné rostliny mohou mít zcela odlišné vůně, vlastnosti, účinky a délku nástupu účinků. Př́íprava esenciálního oleje navíc vyžaduje důkladnou znalost rostlin, jejich prostředí a období sběru. Některé rostliny se musí trhat $\mathrm{v}$ určitou denní dobu, některé stromy musí dosahovat určitého stáří a výšky. Na výsledné kvalitě a vlastnostech esenciálního oleje se podílí také skutečnost, zdali rostliny rostou divoce $\mathrm{v}$ prŕrodě nebo jsou biologicky pěstované. Technologické postupy výroby ovlivňují výslednou kvalitu esenciálního oleje, proto např́klad oleje získané destilací bude charakterizovat odlišná vůně, než oleje získané extrakcí. $\mathrm{V}$ prvním prípadě totiž vyšší teplota způsobuje změny složek oleje. Nejpoužívanější technologickým postupem výroby je destilace vodní parou. $K$ dalším postupům patř́ lisování za studena, enfleuráž, extrakce rozpouštědlem nebo extrakce oxidem uhličitým.

Ačkoliv patří destilace vodní parou $\mathrm{k}$ nejčastěji používané metodě extrakce esenciálního oleje $\mathrm{z}$ rostlin, je to nejméně šetrný způsob poškozující jemnější složky oleje. Tímto technologickým postupem výroby se však zpracovává velké množství sušeného i čerstvého rostlinného materiálu. U destilačního procesu je důležitá teplota a doba trvání, protože některé části rostlin jsou citlivé na teplo a jiné zase vyžadují delší dobu destilace. Destilace vodní parou rozlišuje přímou a nepř́mou destilaci. U prrímé destilace je hlavním principem zahřátí rostlinného materiálu ve vodě, kterou přivedeme $\mathrm{k}$ varu. Zahřiváním vzniká pára, přiváděná $\mathrm{k}$ rostlinnému materiálu, čímž dochází k postupnému uvolňování esenciál-

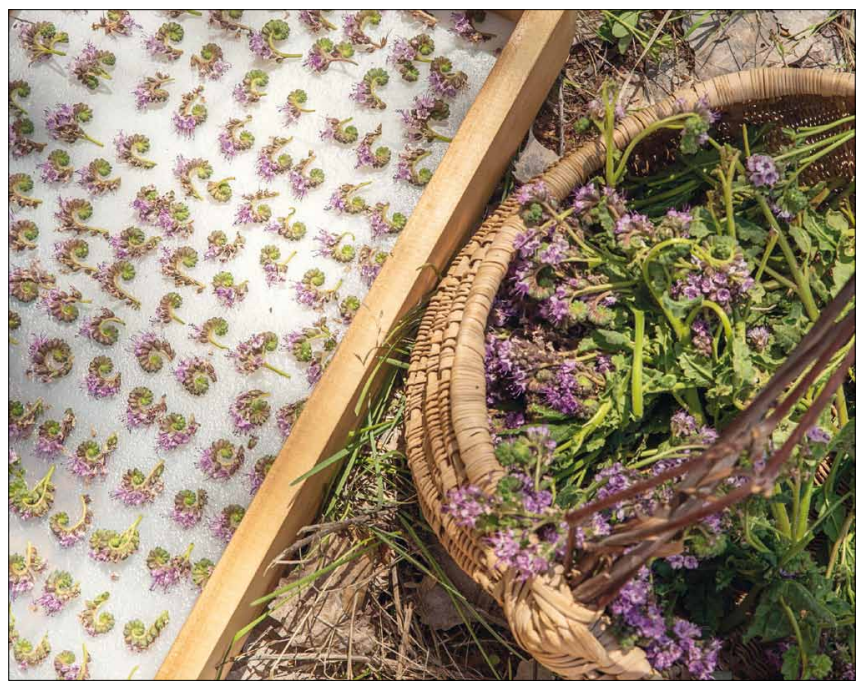

Technologický postup enfleuráž se řadí mezi tradiční způsoby získávání esenciálních olejů vyšší kvality z choulostivých květů rostlin. (c) Calla in Motion.

ního oleje. U nepř́mé destilace se rostlinný materiál umístí na mřížku z nerezové oceli, kterou prochází vodní pára. U obou forem destilace vodní parou, nepř́mé i přímé, dochází při určité teplotě k odpařování kapaliny, která se následně zchladí a vzniklé páry zkondenzují. Pára a voda jsou v tomto př́ípadě nosičem esenciálního oleje (Grosjean 2003; Davisová 2005; Başer - Buchbauer 2010).

U technologického postupu lisování za studena nedochází k zahřátí esenciálního oleje. Tímto postupem se velmi dobře získávají oleje z rostlin, které mají uloženy esenciální oleje ve svých povrchových vrstvách, jako jsou zejména citrusové plody. Oleje jsou v oplodí koncentrovány blízko povrchu slupky, proto je lze získat zmáčknutím a skarifikací nebo i strojovým zpracováním. Ze vzniklé vodnaté emulze se po odstř̌edění oddělí esenciální olej. Ruční zpracování vytváŕí velmi čistý a kvalitní esenciální olej (Davisová 2005; Farrer-Halls 2006; Berger 2007).

Technologický postup enfleuráž (enfleurage) se řadí mezi tradiční způsoby získávání esenciálních olejů vyšší kvality z choulostivých květů rostlin jako tuberóza, fialka nebo jasmín. Enfleuráž se může provádět za studena živočišným tukem nebo za tepla macerací horkým živočišným tukem. Čerstvé okvětní lístky se kladou blízko sebe na skleněné desky nebo plachty mušelínu potřené vrstvou živočišného tuku, který absorbuje esenciální olej. Tento proces se několikrát opakuje, až tuk není schopen absorbovat další esenci. Vzniklá směs - pomáda, se poté smíchá s lihem, který extrahuje esenciální olej z tuku. Technologický postup enfleuráž je časově i finančně náročný a velmi pracný. Získaná esence (absolue) je vysoce koncentrovaná a řadí se mezi drahé oleje (Davisová 2005; Hamid, Aiyelaagbe - Usman 2011).

Extrakce rozpouštědlem představuje nákladný technologický postup výroby esenciálních olejů, který využívá různá rozpouštědla, jako jsou benzen, petroléter, aceton nebo hexan. Vůně získaného esenciálního oleje je závislá na druhu použitého rozpouštědla. Část rostliny se ponoří do rozpouštědla, 


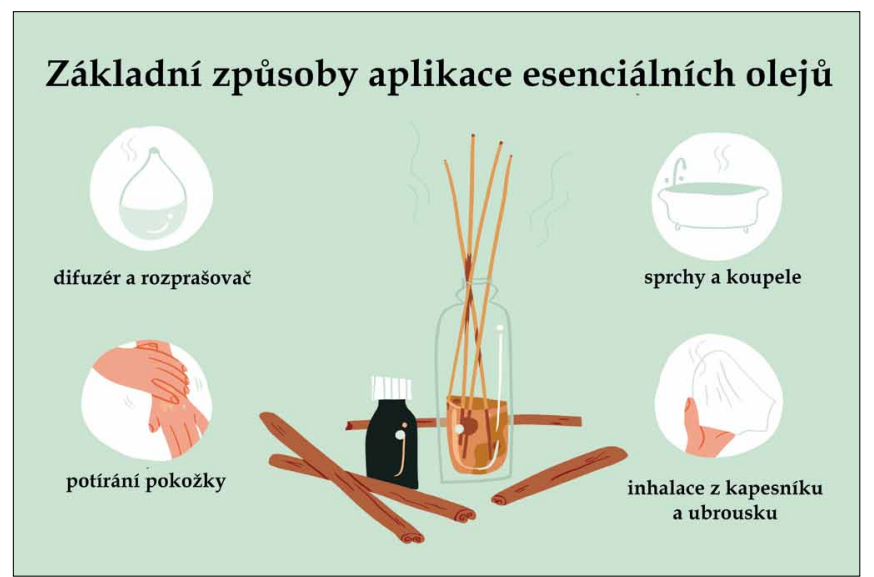

Základní způsoby aplikace esenciálních olejů. (c) Emily Roberts.

které absorbuje esenciální oleje. První produkt se označuje jako konkrétní (konkret). Ten se smíchá s lihem, přefiltruje, zchladí a pak se opakovaně filtruje, aby se odstranily nerozpustné rostlinné vosky. Výsledná extrakce je vymražena a nakonec přefiltrována. Na konci tohoto procesu se získá absolutní extrakt (absolue). Extrakce rozpouštědlem se používá u citlivého rostlinného materiálu nebo rostlinného materiálu s nízkým obsahem esenciálního oleje (Nováková - Šedivý 1996; Salvador - Chisvert 2007, Berger 2007).

Extrakce oxidem uhličitým poskytuje technologický postup výroby, $\mathrm{v}$ jehož průběhu nedochází $\mathrm{k}$ chemické reakci ani k uvolňování tepla. Oxid uhličitý je udržován pod tlakem $\mathrm{v}$ kapalném stavu $\mathrm{v}$ uzavřeném systému s rostlinným materiálem, z něhož se uvolňuje esenciální olej. Tento postup výroby využívá skutečnosti, že nad teplotu $31^{\circ} \mathrm{C}$ (kritickou teplotu) nelze oxid uhličitý dalším zvyšováním tlaku zkapalnit. U vysoce stlačeného plynu s rostoucí hustotou roste i jeho schopnost rozpouštět látky. Extrakce oxidem uhličitým patří mezi nejnákladnější, ale zároveň nejcitlivější postupy výroby esenciálních olejů (Nováková 1996; Grosjean 2003).

\section{ZPU゚SOBY APLIKACE ESENCIÁLNÍCH OLEJŮ}

Aromaterapie využívá dva typy rostlinných preparátů, jimiž jsou esenciální oleje a nosné oleje (nosiče). Esenciální oleje se z důvodu vysoké koncentrace ředí s nosným olejem, který působí na odlišné biochemické úrovni a podílí se na absorpci esenciálního oleje do těla. ${ }^{2}$

2 Nevhodná aplikace esenciálního oleje může mít za následek alergickou reakci, bolest hlavy, podráždění kủže, nevolnost nebo negativní emoce. Při koupi je důležité zohlednit, aby se jednalo o 100\% čistý esenciální olej. Pokud je olej označen jako př́rodně identický olej, př́rodně identické silice nebo př́rodně identická vůně, byl vyroben synteticky a nepředstavuje čistý esenciální olej. Takový olej je ředěný nebo dokonce obsahuje pesticidy, hnojiva a těžké kovy. Kvalitní esenciální olej má na etiketě latinský i český botanický ná-
Neředěné esenciální oleje ${ }^{3}$ se užívají zřídka a ve velmi specifických př́ípadech, jako například levandulový nebo čajovníkový olej na pokožku. Např́klad masážní olej obsahuje přibližně $3 \%$ esenciálního oleje, zbytek tvoří nosný olej. Nosné oleje představují neparfémované rostlinné oleje jako jojobový, mandlový, slunečnicový nebo ořechový. Dále jsou využívány oleje z meruňkových, hroznových nebo broskvových jader. Za nejkvalitnější jsou považovány oleje lisované za studena a nerafinované oleje (MacGilvery 2002; Davisová 2005).

Esenciální oleje se mohou $\mathrm{v}$ aromaterapii aplikovat mnoha způsoby, $\mathrm{k}$ nimž patří vnitřní (interní), aromatické a lokální (topické) užití (Nováková 1996). Esenciální oleje je možné aplikovat jednodruhově nebo použít vícedruhovou směs. Smícháním dvou nebo více esenciálních olejů vzniká synergická směs, jež dosahuje větší účinnosti bez zvýšeného dávkování. Mnohé esenciální oleje charakterizuje adaptogenní (vyrovnávací) působení, které v těle vyvolá vhodnou reakci k dosažení rovnováhy (Worwood 2001). Některé esenciální oleje se mohou odlišovat různým chemickým složením, ačkoliv se jedná o stejný druh rostliny. Jeden druh rostliny může v závislosti na odlišnosti prostředí vykazovat několik chemotypů, $\mathrm{z}$ nichž každý má jiné terapeutické využití. „Stejný druh rostliny, pěstovaný v různých pěstitelských podmínkách, produkuje jiný esenciální olej s jedinečnými vlastnostmi." (Worwood 2012, 66).

Vnitřní užití esenciálních olejů představuje velmi účinnou metodu aplikace, zajištující téměř okamžité proniknutí účinných látek do krevního oběhu a o to rychlejší nástup účinku. Neředěný esenciální olej lze po konzultaci s aromaterapeutem kapat př́mo do úst, do krku nebo do uší. Vnitřní užití vyžaduje obezřetné zacházení, nebot’ esenciální oleje jsou velmi silné alergeny a toxiny. „Podle důležitého zákona př́rody má $i$ všechno blahodárné svou stinnou stránku a může i škodit." (Grosjean 2003, 97) Navíc některé esenciální oleje nejsou vůbec vhodné $\mathrm{k}$ tomuto typu aplikace. Pro pozvolnější vnitřní užití se esenciální oleje naplní do želatinové tobolky, jejíž obsah se uvolní až v žaludku (Lavabre 1996). Vnitřně jsou esenciální oleje užívány i v ústních vodách, kdy působí př́íznivě při léčbě infekce $\mathrm{v}$ ústní dutině a v péči o chrup. Ředěný esenciální olej se může kloktat nebo se jím provádí antiseptický výplach ústní dutiny (Pitman 2004). Některé esenciální oleje jsou také vyhledávány jako přísady do dezertů, džemů, pomazánek nebo likérů a limonád (Farrer-Halls 2007; Noe 2011).

Aromatické užití esenciálních olejů patří k rychlým, jednoduchým a velmi účinným metodám aplikace, která je založena na vdechování esenciálních olejů. Způsoby aromatického užití zahrnují zejména inhalaci a odpařování. Inhalace ne-

zev rostliny, obvykle také zemi původu sběru a část rostliny, z níž byl olej získán.

$3 \mathrm{~V}$ př́ípadě podráždění kůže je tř̌eba zředit esenciální olej s nosným olejem. Dráždivou složkou je zpravidla fenol nebo aromatický aldehyd. Před použitím esenciálního oleje je možné provést jednoduchý test snášenlivosti, kdy se esenciální olej naředí 1:10 s nosným olejem, aplikuje se na malou část předloktí nebo zápěstí a nechá se působit 24 hodin. 


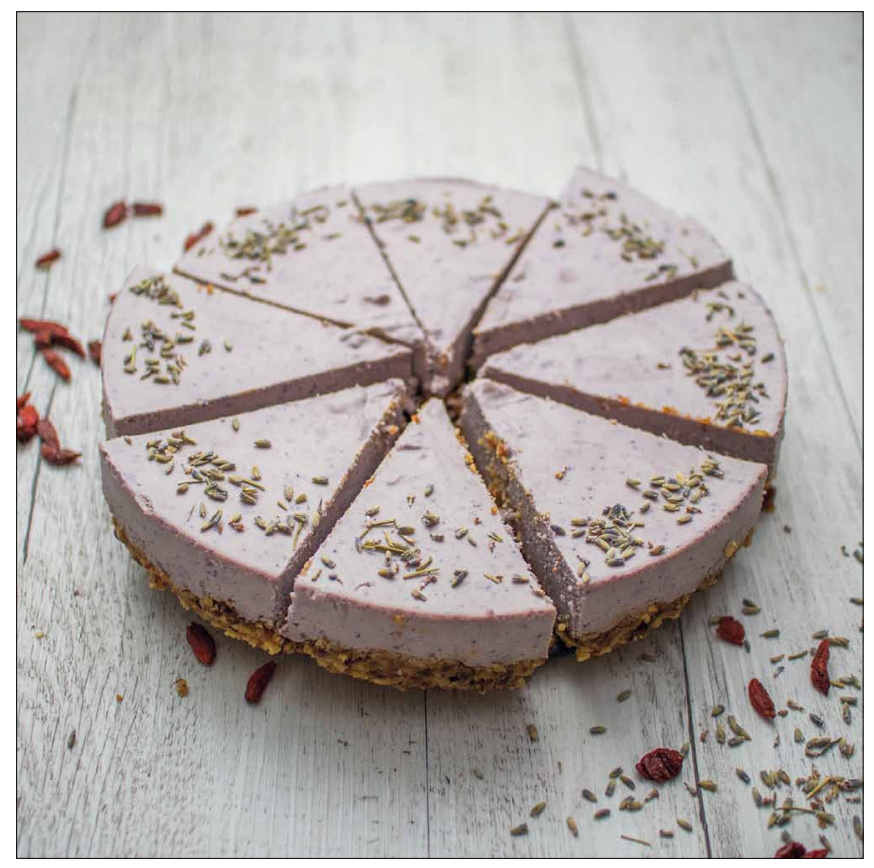

Některé esenciální oleje jsou např́iklad vyhledávány jako př́ísady do dortů cheesecake s esenciálním levandulovým olejem. @ Hazel \& Cacao.

představuje pouze parní inhalaci nad nádobou a v obličejové sauně, ale také inhalaci př́mo $\mathrm{z}$ lahvičky nebo $\mathrm{z}$ dlaně, kapesníku anebo ubrousku a inhalační tyčinky. Při parní inhalaci obsahuje pára molekuly esenciálního oleje, které vdechujeme nosem. Takto inhalovaná látka pronikne do čichového centra v mozku, kde začne ovlivňovat autonomní nervový systém (Wilson 2002; Pitman 2004). Parní inhalace také čistí pokožku obličeje. Inhalovat lze ale také přímo z lahvičky nebo dlaně, v níž je rozetřen esenciální olej. Podobně je možné esenciální olej nakapat na kapesník nebo ubrousek a vdechovat. Inhalační tyčinka je typem kapesního inhalátoru. Uvnitř obsahuje tamponek, na nějž se podle potřeby nakape esenciální olej (Falsetto 2014).

Odpařování využivá esenciálního oleje rozptýleného ve vzduchu, jenž je odpařován $\mathrm{z}$ neglazované nádoby, klasické glazované a elektrické aromalampy nebo rozprašovače, difuzéru a také aroma šperku (Noe 2014; Ali - Al-Wabel - Shams et al. 2015). Odpařování je často využíváno $\mathrm{k}$ aromatizaci vzduchu $\mathrm{v}$ interiérech, a proto jsou používány další výrobky a postupy, jako např́iklad aromakámen nebo aromakniha, vonný polštářek, libovůně (potpourri), kuřidlo anebo svíčka. V neposlední řadě lze esenciální olej nakapat na topivo do krbu, při jehož spalování se bude uvolňovat konkrétní vůně. Do odpařování je možné zařadit i vlhký úklid, kdy se esenciální olej smíchá $s$ horkou vodou určenou $k$ očištění povrchů. Oproti aromalampě vykazuje lepší vlastnosti difuzér, rozptylující do prostředí mechanickým rozvibrováním mikročástice oleje, čímž nedochází $\mathrm{k}$ jejich znehodnocení přepálením. U difuzéru je způsob odpařování zajištěn bez zahřátí, takže chemické složení esenciálního oleje zůstává beze změny (Wilson 2012; Falsetto 2014). Aromašperk je zpravidla náhrdelník nebo náramek vol-

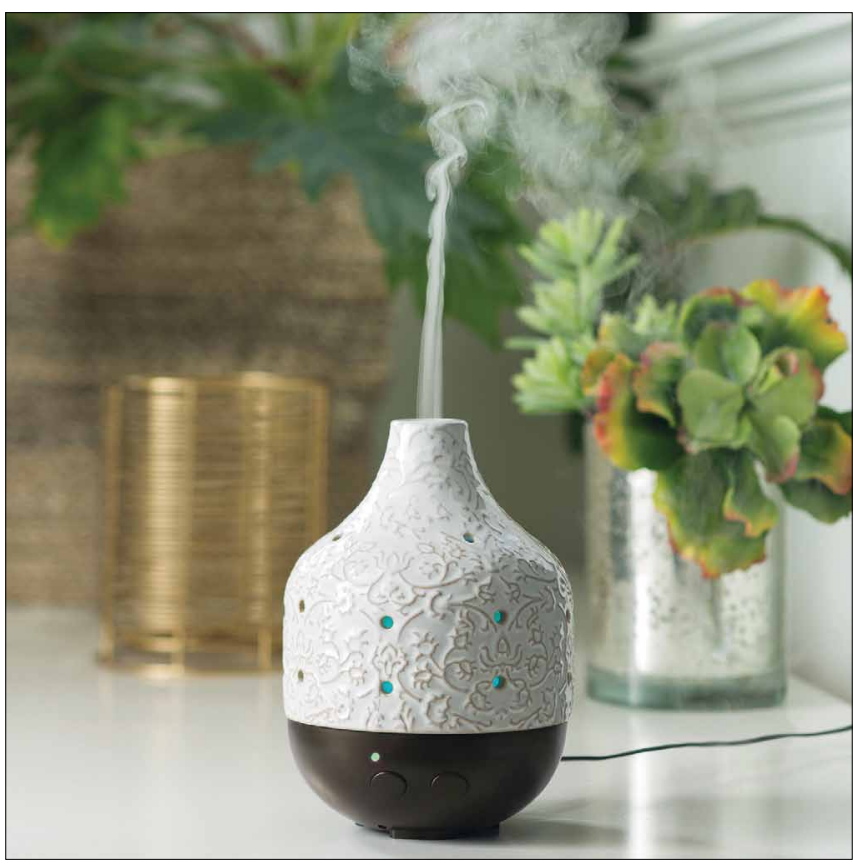

Odpařování využívá rozptýleného esenciálního oleje ve vzduchu, jenž může být odpařován difuzérem. (C) Wayfair.

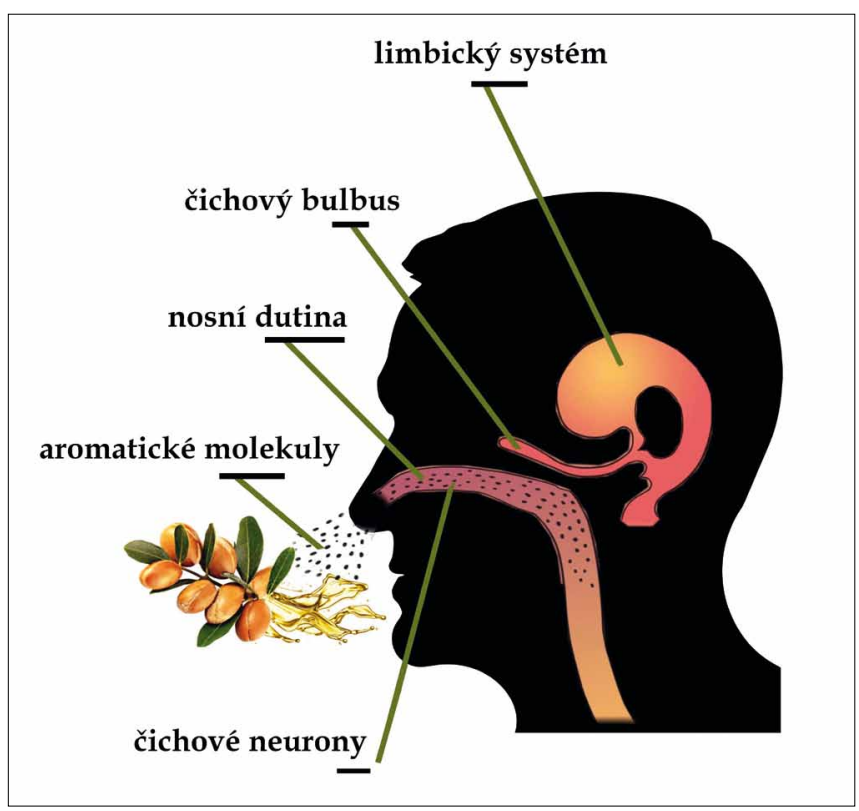

Esenciální oleje a čichový systém. () Token Rock.

ně odpařující esenciální olej z tamponku nebo destičky z porézního materiálu, které jsou uložené uvnitř. Aromakámen může být jakýkoliv porézní kámen, na jehož povrch se nakape několik kapek esenciálního oleje (Cooksley 2002). Aromakniha je prosycena vưní esenciálního oleje, s nímž byla uzavřena několik dní v izolované a temné nádobě. Vonný polštářek obsahuje sušené rostliny, pohanku nebo otruby. Jeho bavlněný potah je po vyprchání vůně pokapán esenciálním olejem. Podobně je možné pár kapek esenciálního oleje nanést na prostě- 


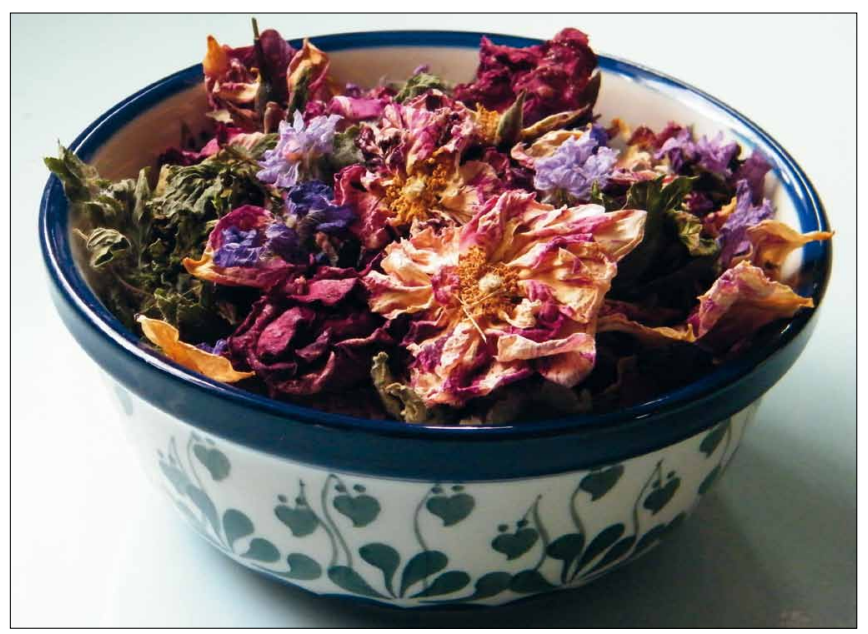

Přirozená vůně sušených rostlin (potpourri) může být oživena kapkami esenciálního oleje. (C) Barbora Půtová.

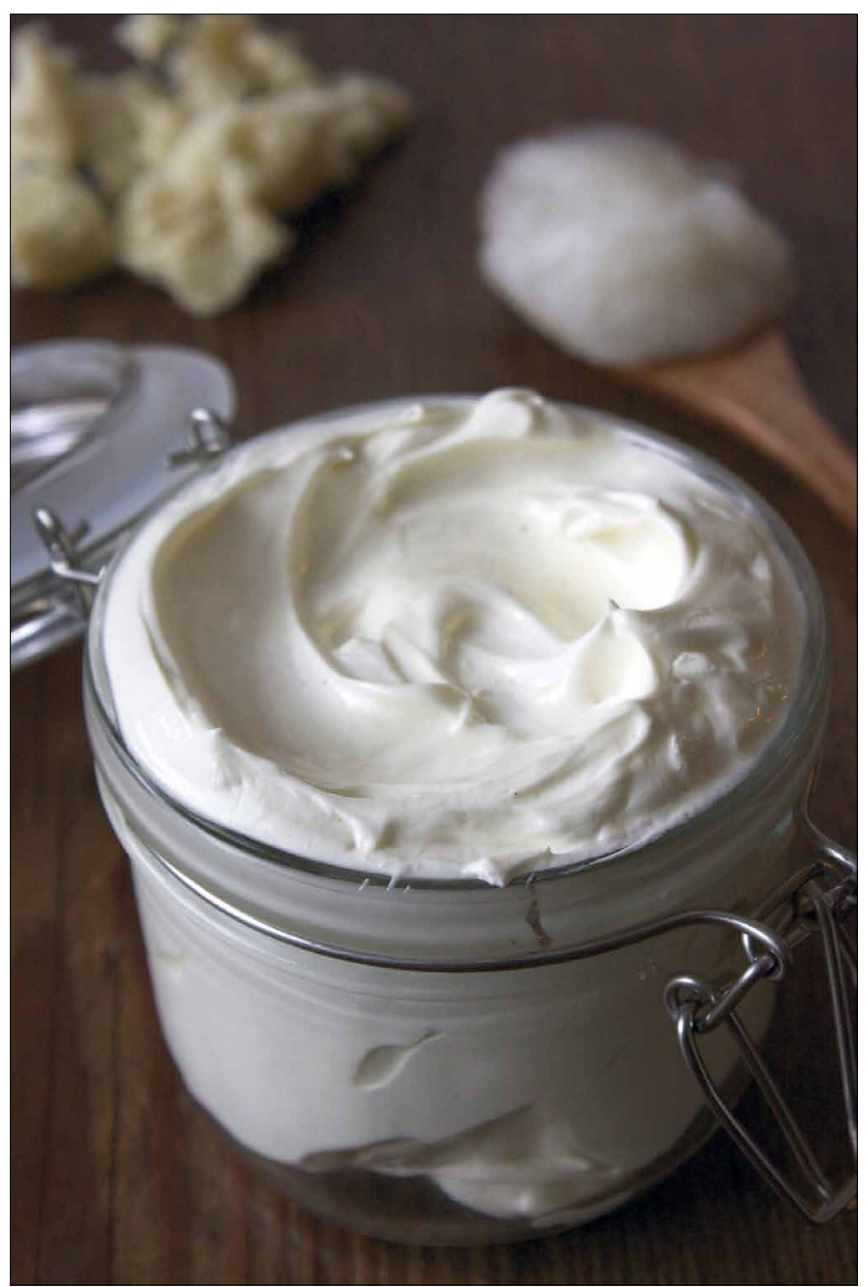

Lokální užití charakterizuje aplikaci esenciálního oleje přímo na kůži - domácí pletový krém s esenciálními oleji. (C) Barbora Půtová.

radlo nebo cíp ložního polštáře. Libovůně tvoří sušené rostliny, jejichž přirozená vůně je oživena kapkami esenciálního oleje. Nejvyhledávanější formou kuřidla jsou vonné tyčinky a také františky nebo kadidlo obsahující esenciální oleje, které jsou často využívané k meditaci, relaxaci nebo cvičení. Svíčka může být napuštěná esenciálním olejem $\mathrm{v}$ blízkosti knotu anebo přímo vyrobená ze směsi vosku a esenciálního oleje (Keville 2016; Sowndhararajan - Kim 2016).

Lokální užití představují aplikaci esenciálního oleje přímo na kůži. Do lokálního užití se řadí potírání pokožky krémy, pletovými vodami a dalšími pletovými a tělovými prrípravky, masáže, koupele, sprchy, vírivky, sauny a obklady (zábaly). Součástí lokálního užití je pletová kosmetika s esenciálními oleji nebo aromatizace oblečení a oděvních doplňků esenciálními oleji (šály, šátky, rukavice, spony do vlasů), s nimiž kůže a různé části těla vstupují do kontaktu (Cerempei 2017). Do lokálního užití patří i různé metody tradiční čínské medicíny jako moxování (zahřívání), baňkování, akupunktura, huoliao (ohnivá terapie) nebo guasha (masáž nefritovou destičkou), které rozšiřují a posilují původní potenciál léčby o esenciální oleje (Kotskirilos - Vietta - Sali 2011). Aromaterapeutická masáž se provádí ručními hmaty měkkých tkání těla. Po technické stránce se neodlišuje od klasické masáže, ale navíc uživá ředěný esenciální olej zahřátý na tělesnou teplotu. Aromatická masáž může být celotělová i zaměřená na postižené části těla a lokální poranění. V průběhu aromaterapeutické masáže se esenciální oleje vstřebávají pokožkou, ale zároveň působí prostřednictvím dýchacích orgánů při inhalaci a vnímání vůně čichem. Esenciální oleje jsou rozpustné v lipidech a pokožkou jsou rychle absorbovány. Tření způsobené masáží podporuje rozšíření cév ve škáře, která zvyšuje absorpci esenciálních olejů. Aromaterapeutická masáž je prospěšná pro zmírnění napětí a stresu, dále zlepšuje cirkulaci krve a správnou činnost lymfy (Goldberg 2001; Gould 2003; Freeman 2004).

Aromaterapeutické koupele jsou založeny na spojení vodní lázně a esenciálního oleje. Voda a olej se ale vzájemně nemísí, proto je do koupele nutné přidat emulgátor, nejčastěji med, mléko, smetanu nebo mořskou sůl. Teplota vody by neměla převyšovat teplotu lidského těla, aby nedocházelo k zatížení srdeční činnosti, krevního oběhu a vysušování kůže. V aromaterapeutické koupeli by měl člověk zůstat alespoň 10 minut, aby do těla proniklo dostatečné množství účinných látek. Podobně jako $v$ př́padě masáže může kůže přímo absorbovat účinné látky a zároveň dochází $\mathrm{k}$ inhalaci vodní páry s esenciálními oleji. Ačkoliv se aromaterapeutická koupel nejčastěji uživá k relaxaci a regeneraci, dokáže léčit kožní problémy a uvolnit namožené svaly. Koupel může být celotělová i zaměřená na konkrétní části těla jako koupel rukou, nohou nebo sedací koupel. Rychlejší a kratší způsob lokální aplikace představuje sprchování, $\mathrm{v}$ jehož průběhu jsou použita sprchová tělová mléka s esenciálními oleji, případně se esenciální oleje nakapou přímo na mycí žínku (Lavabre 1996; Sibley 2008). Esenciální oleje je možné používat ve vířivce a v sauně. V sauně se esenciální oleje zpravidla přidávají do vědra $s$ vodou, kterou se pak polévají kameny. „Vzhledem $k$ tomu, že se prostory pro saunování natolik odlišují, závisí způsob jejich použití na provedení dané sauny. Esenciální oleje jsou hořlavé, proto se nikdy nedávají na přimý zdroj tepla." (Worwood 2016, 312) 


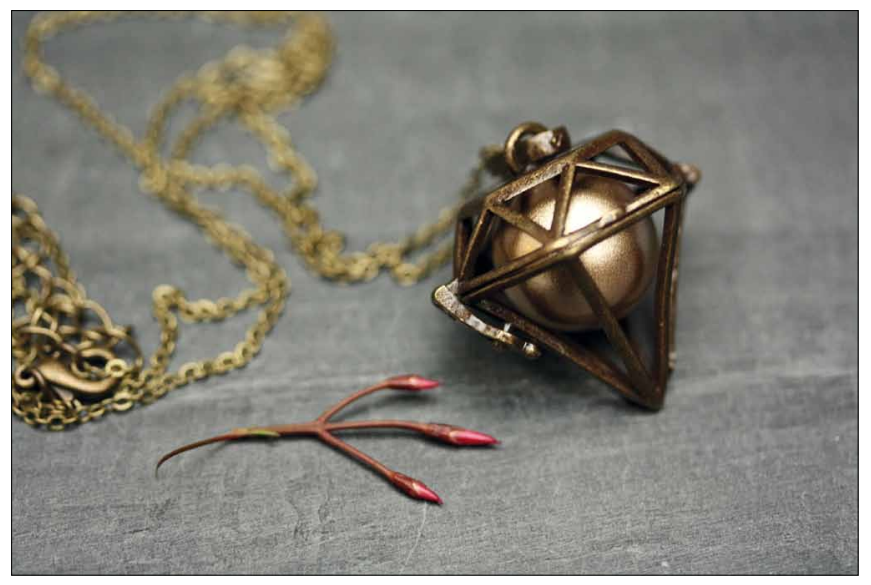

Aromašperk je zpravidla náhrdelník, volně odpařující esenciální olej z uvnitř vloženého tamponku nebo destičky z porézního materiálu. (c) Etsy.

Zvýšením vlhkosti v sauně se rozšiřuje esenciální olej v prostoru. Ve vírivce se esenciální oleje přidávají přímo do vody, jejíž bublání uvolňuje esenciální olej do ovzduší.

Obklady v kombinaci s esenciálními oleji přivádí účinné látky př́mo na postižené místo. Podle druhu léčby se zvolí teplé nebo studené obklady ke zmírnění bolesti, otoků a př́znaků zánětu. Při teplém obkladu je savá látka vložena do horké vody s prríměsí esenciálního oleje, následně je vyždímána a přiložena na konkrétní místo. U teplého obkladu můžeme zvýšit jeho účinnost přiložením lahve naplněné horkou vodou. Jakmile obklad zchladne na tělesnou teplotu, celý proces se znovu opakuje. Teplý obklad uvolňuje tkáně a působí na revmatické postižení, chronické bolesti zad, zubů nebo uší. U studeného obkladu je naopak savá látka vložena do co nejstudenější vody. Studený obklad se užívá na problémy akutní povahy - zmírňuje bolesti hlavy, snižuje horečku a je účinnou první pomocí při kloubních výronech, otocích a namožených svalech. Účinnost obkladu se zvýší přiložením studené lahve s ledem na obklad. Když se začne studený obklad ohřivat, je nutná jeho výměna (Davisová 2005; Houghton 2018).

\section{HISTORIE A SOUČASNOST VNÍMÁNÍ VU゚NĚ ESENCIÁLNÍCH OLEJŮ}

Vnímání vůně je subjektivní dojem a prožitek, který je spojen s audiovizuálními představami, emocemi nebo chutí. Vnímání vưně ovlivňuje několik faktorů, $\mathrm{k}$ nimž patří individuální zkušenosti, kulturní očekávání, věkové nebo genderové rozdíly. Vůně může vyvolat dávno ztracenou vzpomínku z hlubin paměti, silné reakce a prožitky nebo znovupocítění vjemu. Vůně ale nemusí vyvolávat plnohodnotné vzpomínky (Synnott 1993; Houdret 1998; Grosjean 2003; Turin 2006). Podobá se nostalgii, která se „nevztahuje ke konkrétní vzpomínce, ale spíše k emočnímu rozpoložení. Tento idealizovaný emoční stav je orámován minulostí" (Hirsch 1992, 390). Vůni proto vnímáme hedonisticky a posuzujeme ji nejdříve emočně a až následně rozumově. Složitost vůně se projevuje jak ve vnímá-

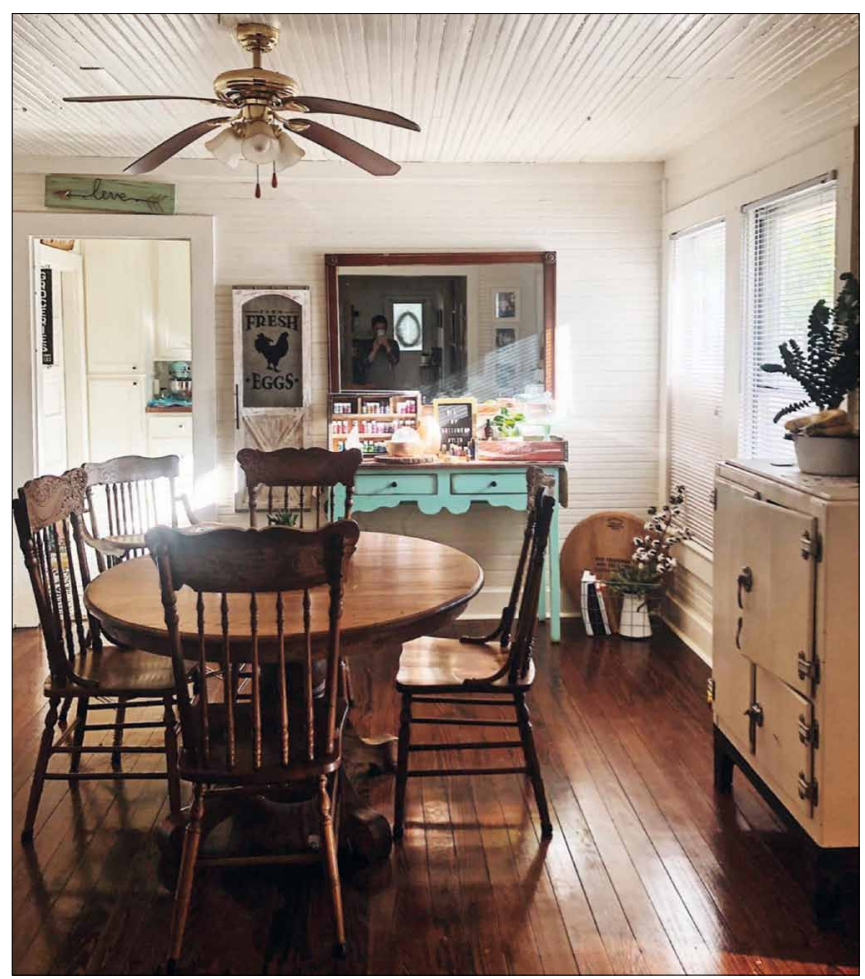

Esenciální olej může sloužit i k úklidu interiéru, kdy se smíchá s čisticím prostředkem nebo horkou vodou určenou k očištění povrchů. (C) The Mushy Mommy.

ní, tak v účincích esenciálních olejů. Esenciální oleje mohou vykazovat odlišné psychologické a fyziologické účinky, které ovlivňuje „terén“ konkrétního uživatele (Tisserand 1992; Wilson - Stevenson 2010). Objektivní farmakologické vlastnosti esenciálních olejů produkují prokazatelné a současně nepředvídatelné účinky. Reakce na vưně tvoří komplex objektivních farmakologických vlastností, osobních zkušeností a kulturních kontextů, $\mathrm{v}$ nichž jsou vůně prožívány, oceňovány a rozpoznávány. Vůně jsou napojeny na kulturní nebo i marketingové mýty, jež se stávají skutečnou součástí zážitku uživatele esenciálních olejů. Kulturní a individuální kontext a očekávání se podílí na fenomenologickém zážitku v léčbě aromaterapií.

$\mathrm{V}$ rovině vnímání vůně je potřeba odlišit esenciální oleje a prŕrodně identické oleje, jejichž vůně se sice mohou podobat, ale nemají žádné farmakologické a terapeutické vlastnosti. V dnešní době, kdy syntetická vůně ovládá čichovou krajinu, není důležitá materiální přítomnost vůně. Syntetické vůně „evokují věci, které tam nejsou, přítomnost, která je neprítomná" (Classen - Howes - Synnott 1994, 205). To se podílí na vnímání vůně esenciálních olejů současnými uživateli, kteří mohou být zklamaní $\mathrm{z}$ přírodního charakteru vůně. Necítí totiž vůni, na kterou jsou zvyklí. Z těchto důvodů se mnozí rozhodnou i nadále používat syntetické produkty. Jiní uživatelé naopak rádi poznají nové produkty a rozšírí svoje znalosti v oblasti aromaterapie. Existence a množství esenciálních olejů a přírodně identických olejů spoluvytváří nové 


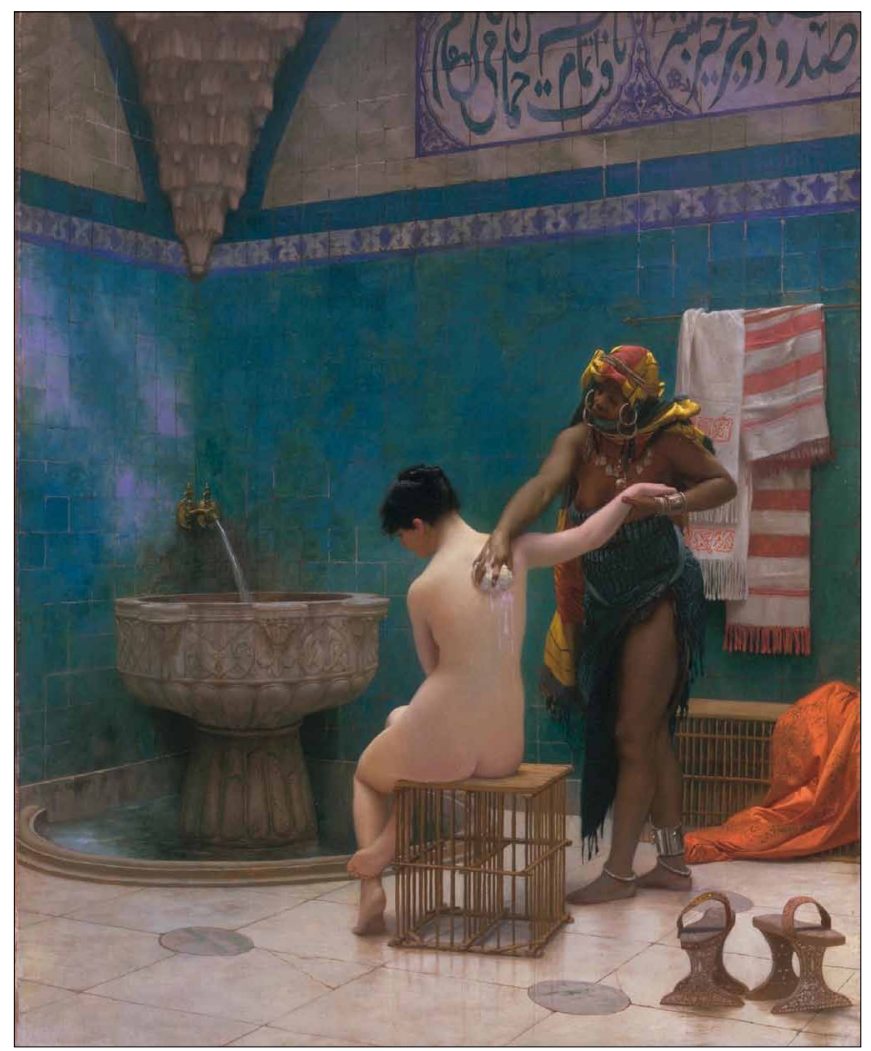

Esenciální oleje doprovází morální nejistota a ambivalence k světskému užívání vůní vyplývající z jejich užívání za účelem zkrášlení nebo přitažlivosti těla v interiéru příbytku, jako například v harému a tureckých lázních. Francouzský malíř Jean-Léon Gérôme, olejomalba Lázeň (1880-1885). @ AMICA Library.

typy výrobků, nové typy uživatelů a konkrétní reakce na vůně. Esenciální oleje historicky ztělesňují tři principy provázané s vůní. Esenciální oleje 1 . jsou naplněny symboly a významy, 2. vyjadřují životní sílu a vitalitu rostliny a 3. vyžadují holistický prrístup. Esenciální oleje charakterizují symboly a významy nebo různé pravdy a prezentace. Esenciální oleje doprovází morální nejistota a ambivalence světské aplikace vůní vyplývající z jejich užívání v interiéru příbytku, jako např́iklad $\mathrm{v}$ harému a tureckých lázních, a za účelem zkrášlení nebo přitažlivosti těla. Některé vůně navozují lehkost a rozptýlení, některé jsou zase považovány za povznášející. Tento rozpor se promítá i do současné marketingové komunikace. Vůně mohou být oceňovány jako vzácné nebo odsuzovány jako záliba bohatých lidí, žen, homosexuálů, metrosexuálů nebo dandyů. Vůně esenciálních olejů je naplněná rozpory, které se vztahují k feminizaci, romantizaci, trivialitě, marnosti, efemérnosti nebo neautenticitě (King 1994; Wheeler Robins 1999). Esenciální oleje vyjadřují životní sílu a vitalitu rostliny, která je použita jako nástroj léčby a uzdravení. Esence rostliny představuje její duši. „Jsou jako osobnost nebo druh rostliny. " (Tisserand 1992, 8) Esenciální oleje koncentrují živou a komunikativní podstatu bylin, stromů, koření, ovoce nebo trav, poskytující lidskému tělu vitální prvek a energii (Schiller 1999). Základním nositelem energie je i slunce, protože „rostliny zachycují elektromagnetickou energii ze slunce a její část se ukládá v esenciálním oleji“ (Price - Price 1995, 70). V této rovině je celý svět chápán jako živý organismus, v němž neexistuje dělení na organickou a anorganickou hmotu nebo živou a neživou př́rodu. V aromaterapii vyžaduje vůně, její terapeutické vlastnosti a symbolické významy holistický prístup. Vůně není chápána pouze jako dekorativní, povrchní nebo radostná esence, ačkoliv nelze opomenout luxusní a pečující vlastnosti nebo vzácnost esenciálních olejů. V aromaterapii je vůně vícevrstvá, protože propojuje vědecké, historické (mytologické) a terapeutické vlastnosti. Esenciální oleje mohou posílit naši vnitřní bytost a vytvořit ochranný štít jejímu uživateli. Nabízí dar síly a odvahy, odhalují životní krásu a pomáhají léčit onemocnění nebo jeho prvotní príźznaky. Esenciální oleje jsou „osobnosti“, mohou být společníky, utěšiteli nebo učiteli, kteří uživatele doprovází v péči o tělo i duši. Esenciální oleje vstupují zpět do minulosti, v níž vůně evokovala posvátno a v níž byly rostliny a jejich účinky využíány a oceňovány (Maury 1974; Classen - Howes - Synnott 1994).

\section{KOMODIFIKACE AROMATERAPIE A ESENCIÁLNÍCH OLEJŮ}

Aromaterapie stále více proniká do kosmetického, parfumérského, farmaceutického a potravinářského průmyslu. Esenciální oleje se proměňují v produkty, které jsou prodávány jako komodity. Trh s aromaterapií zaznamenal expanzi, která může $\mathrm{v}$ důsledku ohrožovat nároky kladené na kvalitu, specifické podmínky pěstování a výroby i účinnost esenciálních olejů. Hlavní proud aromaterapie upozaduje medicínskou aromaterapii a ovlivňuje komodifikaci vůně. V této spotřební krajině může aromaterapie vystupovat jako nika $\mathrm{v}$ rámci široké komodifikace vůně ve službách kosmetického průmyslu. Primárními se stávají způsoby spotřeby esenciálních olejů a s nimi spojené významy a nikoliv vlastnosti esenciálních olejů, které byly použité pro jeho výrobu. „Od této chvíle jsou to samotné objekty, které poutají naši pozornost, již ne materiály, z nichž jsou vyrobeny. "(Ingold 2011, 26) Významy spojené s materiálními objekty, $\mathrm{v}$ tomto př́padě esenciálními oleji, závisí na sociálně-kulturním kontextu. Tento kontext představuje arénu, jež je poznamenána transakcemi a významy (Appadurai 1986). Různé hodnoty jsou např́íklad spojeny s esenciálními oleji, pokud jsou prodávány jako parfém, toaletní nebo parfémová voda. Esenciální oleje jsou komoditou, s níž se obchoduje, která je doporučována, užívána a konzumována. Esenciální oleje žijí své vlastní životy a sledují své vlastní kariéry, v nichž jsou produkovány, distribuovány, př́ípadně předepisovány, až nakonec zažívají vlastní smrt prostřednictvím konzumace a život po smrti ve formě účinku v lidském těle (van der Geest 1991; van der Geest et al. 1996; Whyte - van der Geest - Hardon 2002).

Komodifikovaná verze aromaterapie je součástí kosmetického průmyslu, čímž přijímá represivní a normalizující ideologii feminity a ženské krásy. Šíření aromaterapie jako produktu léčebného postupu, esenciálního oleje nebo aromalampy - je také podporováno „kapitalistickou nutností rozdělit produkto- 
vou řadu stejně jako tělo, mysl a ducha do co nejvíce částí v zájmu zajištění stále rostoucího trhu a spotřebitelské základny." (Lau 2000, 35) Esenciální oleje mohou podporovat členění těla na části, z nichž každá vyžaduje svůj samostatný aromaterapeutický produkt, jako např́klad pletový krém na obličej nebo šampon na vlasy. Tak vzniká sbírka produktů, která fragmentuje tělo do řady částí a odděluje mysl a duši. Každá č́st těla je "léčitelná" různými produkty aromaterapie. Komodifikovaná verze aromaterapie velmi často ústí ve spekulativní rovnici, podle níž přírodní produkty ústí v environmentální přínos. Někteři uživatelé aromaterapie totiž vyznávají alternativní způsob života, jehož součástí je odmítání petrochemických a jiných syntetických produktů. Aromaterapie se proměňuje ve znak něčeho jiného, je projevem společnosti, v níž lidé úzkostlivě hledí na moderní život jako na toxický. V aromaterapii je proto zakotveno i nostalgické zavržení modernity a technologie. Její spotřebitelé hledají kořeny aromaterapie $\mathrm{v}$ lidovém léčitelství. Jedná se o romantizaci, která přehlíží lidské a ekologické důsledky toho, že současní spotřebitelé aromaterapie nesbírají části rostlin, keřů nebo stromů v lesích a na loukách, ale zakupují již hotové esenciální oleje v obchodech.

\section{ZÁVĚR}

V současnosti je obtížné vyvážit komerční prodej a distribuci esenciálních olejů a zároveň zachovat hlavní poselství aromaterapie. V aromaterapii by i nadále měly být vyzdvihovány původní holistické požadavky, které respektují a podporují subjektivitu jedince, jeho osobní růst a individualizovanou léčbu: „je důležité zachovat celistvost esenciálního oleje, aby byla ochráněna jeho přirozená synergie ( $z$ řeckého syn = společně,

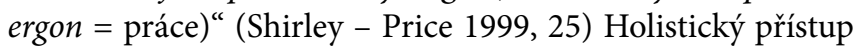
ke klientovi souvisí i s jeho svobodnou volbou esenciálního oleje i způsobu aplikace za podpory léčitele nebo aromaterapeuta. Ve výběru esenciálního oleje by se měla projevovat svobodná volba klienta na základě vưně a vědomí $\mathrm{i}$ víry v jeho různé a i pozvolné účinky (Mailhebiau 1995). Esenciální oleje totiž nesledují krátkodobé nebo povrchní cíle, naopak usilují obnovit zdravé a přirozené reakce. Jejich cílem je vnášet do života kompletní a inteligentní informaci a způsobovat skutečnou a hlubokou změnu. Poučený uživatel v důsledku nevnímá esenciální oleje jako elixíry tajemného složení z alchymistické dílny, jejichž tajemnost posiluje i spojování vědecké terminologie s jazykem emocí (například esenciální oleje mají sladké, čerstvé nebo květinové vůně).

Při výběru esenciálního oleje však do popředí vystupuje značka (brand) esenciálních olejů, jež velmi často upozaduje osobnost aromaterapeuta nebo léčitele jako zdroje spolehlivých informací ohledně složení a účinnosti přírodních produktů. Zvyšuje se nejenom konkurence $\mathrm{v}$ oblasti nabídky esenciálních olejů, ale také kupní síla a různé typologie spotřebitelů neboli klientů, kteří na straně jedné hledají hodnotu a nejlepší produkt na trhu, nebo na straně druhé pouze výhodný nákup (Banks 2014). Z tohoto důvodu by čisté esenciální oleje měly

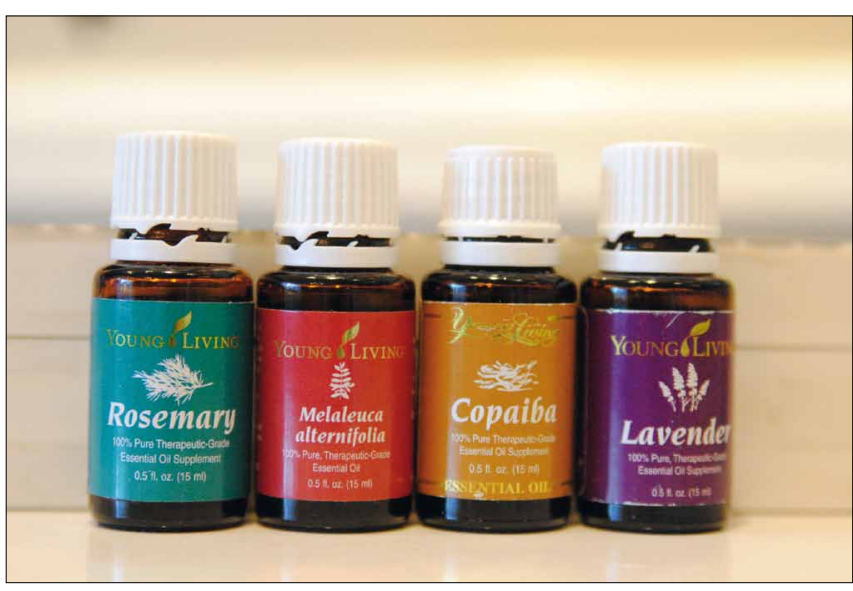

Při výběru esenciálního oleje do popředí vystupuje značka (brand) esenciálních olejů. Americká společnost Young Living je výrobcem 100\% čistých přírodních esenciálních olejů nejvyšší kvality, jehož popularita narůstá na českém trhu. (C) Barbora Půtová

být nabízeny výhradně $\mathrm{v}$ ordinaci aromaterapeuta a léčitele nebo ve specializovaných prodejnách a obchodech, v nichž zákazníci dostanou základní informace o složení a instrukce $\mathrm{k}$ aplikaci esenciálních olejů.

Zatímco standardizace je ústředním cílem biomedicíny a farmaceutického průmyslu, standardizace esenciálních olejů je $\mathrm{v}$ rozporu nejenom s holistickou filozofií aromaterapie, ale i lokální povahou rostliny, která roste ve svém přirozeném životním prostředí. Na rozdíl od medikamentů vyráběných v laboratořích za vysoce kontrolovaných podmínek, rostliny nerostou stejnoměrně ani neprodukují identické směsi sloučenin ve stejném poměru. Tuto přirozenou rozmanitost je obtížné prosadit v biomedicínském prostředí, v němž jsou výrobní postupy neustále zefektivňovány a jsou preferována levnější generická léčiva (Ross 2012). V porovnání s biomedicínou může aromaterapie představovat bezpečnou, účinnou a léčivou alternativu $\mathrm{k}$ farmaceutickým výrobkům a př́pravkům.

\section{LITERATURA}

Ali, B. - Al-Wabel, N. A. - Shams, S. et al. (2015): Essential Oils Used in Aromatherapy: A Systemic Review. Asian Pacific Journal of Tropical Biomedicine 5(8), 601-611.

Appadurai, A. (1986): Introduction: Commodities and the Politics of Value. In Appadurai, A. (Ed.), The Social Life of Things: Commodities in Cultural Perspective. Cambridge: Cambridge University Press, 3-63.

Aazza, S. - Lyoussi, B. - Megías, C. et al. (2014): Anti-Oxidant, Anti-Inflammatory and Anti-Proliferative Activities of Moroccan Commercial Essential Oils. Natural Product Communications 9(4), 587-594.

Atkinson, A. (2015): Essential Oils for Beauty, Wellness, and the Home: 100 Natural, Non-toxic Recipes for the Beginner and Beyond. New York: Skyhorse Publishing.

Bach, E. (2010): Heal Thyself. New York: Random House.

Baer, H. - Singer, M. (1997): Medical Anthropology and the World System: A Critical Perspective. Westport: Bergin \& Garvey.

Banks, S. R. (2014): Revelation!: Reveal Your Destiny with Essential Oils. Bloomington: Balboa Press.

Başer, K. H. C. - Buchbauer, G. (2010): Handbook of Essential Oils: Science, Technology, and Applications. Boca Raton: CRC Press, Taylor \& Francis. 
Berger, R. (2007): Flavours and Fragrances Chemistry, Bioprocessing, and Sustainability. Berlin: Springer-Verlag.

Calcabrini, A. - Stringaro, A. - Toccacieli, L. et al. (2004): Terpinen-4-ol, The Main Component of Melaleuca Alternifolia (Tea Tree) Oil Inhibits the In Vitro Growth of Human Melanoma Cells. Journal of Investigative Dermatology 122(2), 349-360.

Cerempei, A. (2017): Aromatherapeutic Textiles. IntechOpen, http://dx.doi. org/10.5772/66544

Classen, C. - Howes, D. - Synnott, A. (1994): Aroma: The Cultural History of Smell. London: Routledge.

Cooksley, V. G. (2002): Aromatherapy: Soothing Remedies to Restore, Rejuvenate and Heal. Paramus: Prentice Hall.

Damianovi, P., K. (1997): Aromaterapie: Vưně a duše. Využití éterických olejů pro získání tělesné i duševní pohody. Praha: Volvox Globator.

Davis, P. (2005): Aromaterapie od A do Z: V̌se o aromaterapii. Praha: Alternativa.

Falsetto, S. (2014): Authentic Aromatherapy: Essential Oils and Blends for Health. New York: Skyhorse Publishing.

Farrer-Halls, G. (2007): Aromaterapie od A do Z: Podrobný průvodce světem esenciálních olejü. Praha: Metafora.

Frankenberg, R. (1980): Medical Anthropology and Development: A Theoretical Perspective. Social Science and Medicine 14B, 197-207.

Freeman, L. W. (2004): Mosby's Complementary and Alternative Medicine A Research Based Approach. St. Louis: Mosby.

Goldberg, L. (2001): Massage and Aromatherapy: A Practical Approach. Cheltenham: Nelson Thornes.

Gordon, D. (1988): Tenacious Assumptions in Western Medicine. In Lock, M. - Gordon, D. (Eds.), Biomedicine Reconsidered. Dordrecht: Kluwer Academic Publishers, 19-56.

Gould, F. (2003): Aromatherapy for Holistic Therapists. Cheltenham: Nelson Thornes.

Grosjean, N. (2003): Velká kniha aromaterapie: Jak si zachovat zdraví a cítit se dobř pomocí aromatických olejů. Olomouc: Fontána.

Hahn, R. A. - Kleinman, A. (1983): Biomedical Practice and Anthropologica Theory: Frameworks and Directions. Annual Review of Anthropology 12 , 305-333.

Hamid, A. - Aiyelaagbe, O. - Usman, L. (2011): Essential Oils: Its Medicinal and Pharmacological Uses. International Journal of Current Research 33(2), 86-98.

Harding, J. (2003): Tajemství aromaterapie. Praha: Svojtka.

Hertzka, G. - Strehlow, W. (2002): Léčebné umění Hildegardy z Bingenu. Praha: Alternativa.

Hirsch, A. R. (1992): Nostalgia: A Neuropsychiatric Understanding. Advances in Consumer Research 19, 390-395.

Hongratanaworakit, T. (2004): Physiological Effects in Aromatherapy. Song klanakarin Journal of Science and Technology 26(1), 117-125.

Houdret, J.-C. (1998): Vưně, která léćí. Praha: Volvox Globator.

Houghton, M. (2018): In Focus Essential Oils and Aromatherapy: Your Personal Guide. Minneapolis: Book Sales.

Chouhan, S.- Sharma, K. - Guleria, S. (2017): Antimicrobial Activity of Some Essential Oils: Present Status and Future Perspectives. Medicines $4,58-79$.

Ingold, T. (2011): Being Alive: Essays on Movement, Knowledge and Description. London: Routledge.

Keville, K. (2016): The Aromatherapy Garden: Growing Fragrant Plants for Happiness and Well-Being. Portland: Timber Press.

King, J. R. (1994): Scientific Status of Aromatherapy. Perspectives in Biology and Medicine 37, 409-415.

Kotskirilos, V. - Vietta, L. - Sali, A. (2011): A Guide to Evidence-Based Integrative and Complementary Medicine. New York: Churchill Livingstone.

Kř́ižová, E. (2015): Alternativní medicína v České republice. Praha: Karolinum.

Lau, K. J. (2000): New Age Capitalism: Making Money East of Eden. Philadelphia: University of Pennsylvania Press.

Lavabre, M. (1996): Aromatherapy Workbook. Rochester: Healing Arts Press. Lavery, S. (1998): Aromaterapie v kostce. Praha: Slovart.

Lieban, R. W. (1977): The Field of Medical Anthropology. In Landy, D. (Ed.), Culture, Disease, and Healing: Studies in Medical Anthropology. New York: Macmillan Publishing, 13-31.

Lis-Balchin, M. (2006): Aromatherapy Science: A Guide for Healthcare Professionals. London: Pharmaceutical Press.
Lock, M. - Nguyen, V. K. (2010): An Anthropology of Biomedicine. Oxford: Wiley-Blackwell.

Mailhebiau, P. (1995): Portraits in Oils: The Personality of Aromatherapy Oils and Their Link with Human Temperaments. Saffron Walden: CW Daniel Co.

Maury, M. (1974): Secret of Life and Youth: Regeneration Through Essential Oils. A Modern Alchemy. London: Macdonald.

McGilvery, C. (2002): Aromaterapie, masáž, jóga. Praha: Svojtka \& Co.

Noe, M. (2011): Dobré věci nejsou špatné: Kniha zdravějšího vaření a pečení. Praha: One Woman Press.

Morag, N. (2011): Essential Oils for Animals. Florida: Off the Leash Press.

Noe, M. (2014): Aromaterapie do kapsy: Malá encyklopedie éterických oleju․ Praha: One Woman Press.

Nováková, B. - Šedivý, Z. (1996): Praktická aromaterapie. Praha: Pragma

Pavela, R. (2006): Rostlinné insekticidy: Hubíme hmyz bez chemie. Praha: Grada.

Pitman, V. (2004): Aromatherapy: A Practical Approach. Cheltenham: Nelson Thornes.

Poole, R. - Gessler, W. (2005): Medical Anthropology: Understanding Public Health. New York: Open University Press.

Price, S. (1993): Aromatherapy Workbook. London: Thorsons.

Price, S. - Price, L. (1995): Aromatherapy for Health Professionals. Edinburgh: Churchill Livingstone.

Rhind, J. P. (2012): Essential Oils: A Handbook for Aromatherapy Practice Second. London: Singing Dragon.

Ross, A. L. (2012): The Anthropology of Alternative Medicine. New York: Berg

Salvador, A. - Chisvert, A. (Eds.) (2007): Analysis of Cosmetic Products. Amsterdam: Elsevier.

Schiller, R. (1999): Svatá Hildegarda a její léčebné metody: Léčení v souladu s prírodou. Zachování prvotních životních sil. Praha: Ikar.

Sibley, V. (2008): Aromaterapie pro každého: Esenciální oleje pro povzbuzen mysli, těla a duše. Praha: Svojtka \& Co.

Skaria, B. P. (2007): Aromatic Plants. Delhi: New India Publishing.

Slepičková, L. - Šlesingerová, E. - Šmídová, I. (2012): Biomoc a reprodukční biomedicína: Konceptuální inspirace pro česky kontext. Sociologický časopis $48(1), 85-106$.

Sommer, S. J. (1996): Mind-body Medicine and Holistic Approaches: The Scientific Evidence. Australian Family Physician 25(8), 1233-1237, 1240-1241, 1244.

Snyder, M. - Lindquist, R. (Eds.) (2006): Complementary and Alternative Therapies in Nursing. New York: Springer.

Snyder, M. (2019): The Essential Oils Hormone Solution, Reclaim Your Energy and Focus and Lose Weight Naturally. New York: Rodale.

Sowndhararajan, K. - Kim, S. (2016): Influence of Fragrances on Human Psychophysiological Activity: With Special Reference to Human Electroencephalographic Response. Scientia Pharmaceutica 84(4), 724-751.

Stoner, B. P. (1986): Understanding Medical Systems: Traditional, Modern, and Syncretic Health Care Alternatives in Medically Pluralistic Societies. Medical Anthropology 17(2), 44-48.

Svoboda, K. P. - Deans, S. G. (1995): Biological Activities of Essential Oils From Selected Aromatic Plants. Acta Horticulture 390, 203-209.

Swamy, M. K. - Akhtar, M. S. - Sinniah, U. R. (2016): Antimicrobial Properties of Plant Essential Oils Against Human Pathogens and Their Mode of Action: An Updated Review. Evidence-Based Complementary and Alternative Medicine 3, 1-21.

Synovitz, L. B. - Larson, K. L. (2013): Complementary and Alternative Medicine for Health Professionals: A Holistic Approach to Consumer Health. Burlington: Jones \& Bartlett Learning.

Synnott, A. (1993): The Body Social: Symbolism, Self and Society. London: Routledge.

Tiran, D. (2016): Aromatherapy in Midwifery Practice. London: Singing Dragon.

Tisserand, R. (1992): Umění aromaterapie: Domácí i odborná léčba vonnými esencemi rostlin. Kosmetika, omlazování, chronické i akutní nemoci. Praha: Alternativa.

Tisserand, R. - Young, R. (2014): Essential Oil Safety: A Guide For Health Care Professionals. Edinburgh: Elsevier Limited.

Tomášková, H. (2014): Terapie esenciálními oleji pro vyvážení životní energie: Aromaterapie \& čakry. Staré Hradiště: Hanna Maria Therapy.

Turin, L. (2006): The Secret of Scent: Adventures in Perfume and the Science of Smell. New York: Ecco. 
van der Geest, S. (1991): Pharmaceutical Anthropology: Perspective for Research and Application. In van der Geest, S. - White, S. R. (Eds.), The Context of Medicine in Developing Countries: Studies in Pharmaceutical Anthropology. Amsterdam: Het Spinhuis Publishers, 329-366.

van der Geest, S. - Whyte, S. R. - Hardon, A. (1996): The Anthropology of Pharmaceuticals: Abiographical Approach. Annual Review of Anthropo$\log y 25,153-178$.

Vigan, M. (2010): Essential Oils: Renewal of Interest and Toxicity. European Journal of Dermatology 20, 685-692.

Wheeler Robins, J. L. (1999): The Science and Art of Aromatherapy. Journal of Holistic Nursing 17(1), 5-17.

Whyte, S. R. - van der Geest, S. - Hardon, A. (2002): Social Lives of Medicines. Cambridge: Cambridge University Press.
Wildwood, C. (1996): The Encyclopedia of Aromatherapy. Rochester: Healing Arts Press.

Wilson, D. - Stevenson, R. (2010): Learning to Smell: Olfactory Perception from Neurobiology to Behaviour. Baltimore: John Hopkins University Press.

Wilson, R. (2002): Aromatherapy: Essential Oils for Vibrant Health and Beauty. New York: Avery.

Worwood, V. A. (2001): Aromatherapy for the Beauty Therapist. London: Thompson Learning.

Worwood, V. A. (2012): The Fragrant Heavens: The Spiritual Dimension of Fragrance and Aromatherapy. Novato: New World Library.

Worwood, V. A. (2016): The Complete Book of Essential Oils and Aromatherapy: Revised and Expanded. Novato: New World Library. 